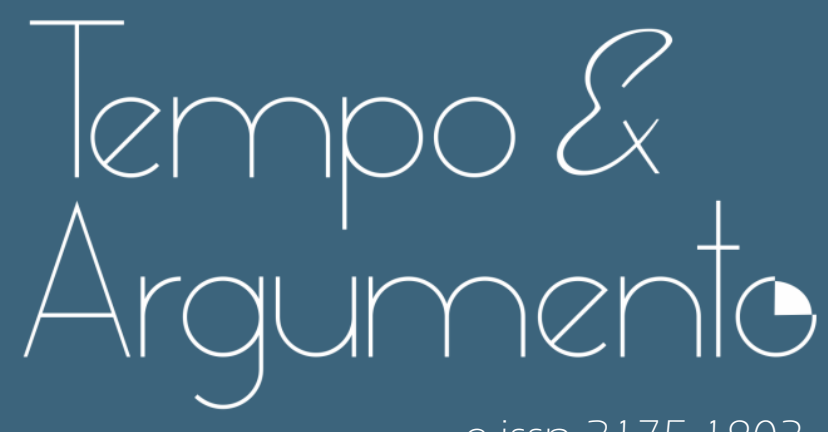

e-issn 2175-1803

A defesa da interrupção voluntaria da gravidez nos cartuns "Abortinho" de Fabiane Langona (2015-2017)

- Maria da Conceição Francisca Pires

Doutora em História Social pela Universidade Federal Fluminense (UFF).

Professora do Programa de Pós-Graduação em História da

Universidade Federal do Estado do Rio de Janeiro (PPGH/UNIRIO).

Rio de Janeiro, RJ - BRASIL

lattes.cnpq.br/9397370787594051

conceicao.pires@uol.com.br

(1) orcid.org/0000-0001-8618-4151

Para citar este artigo:

PIRES, Maria da Conceição Francisca. A defesa da interrupção voluntaria da gravidez nos cartuns "Abortinho" de Fabiane Langona (2015-2017). Tempo e Argumento, Florianópolis, v. 12, n. 31, e0 101 , set./dez. 2020

doi http://dx.doi.org/10.5965/2175180312312020e0 101

Recebido: 05/01/2020

Aprovado: 10/05/2020 


\title{
A defesa da interrupção voluntaria da gravidez nos cartuns "Abortinho" de Fabiane Langona (2015-2017)
}

\begin{abstract}
Resumo
O artigo versa sobre como a defesa da interrupção voluntária da gravidez se tornou um tema abraçado por cartunistas e quadrinistas contemporâneas que se mostram sintonizadas com as demandas feministas, centrando o enfoque na série "Dicas do Abortinho", criada pela cartunista Fabiane Langona. Na primeira parte do texto, apresento de forma breve três trabalhos pontuais que, com abordagens distintas, discutem tabus, mitos e os riscos inerentes à prática do aborto clandestino: a narrativa autobiográfica em forma de HQ desenhada pela cartunista Cynthia B, publicada na revista Piauí, em 2014; o romance gráfico produzido em 2015, pela artista Leah Hayes; e a reportagem gráfica, escrita em 2016 pela jornalista Joyce Gomes e pela quadrinista Helô D’Angelo, autora dos desenhos. Na segunda parte, analiso especificamente o personagem "Abortinho", colocando em relevo as estratégias visuais e discursivas empregadas pela cartunista para tratar desse tema como um problema social e político, ainda que tenha gerado uma significativa hostilidade entre leitores e leitoras. Entendo que a reação à série "Abortinho" se deu menos pelo impacto visual que a série produz sobre seus leitores, do que pela densidade que o tema "aborto" carrega, afinal a defesa dos direitos ao corpo e à liberação do aborto consistem nos maiores desafios enfrentados pelos feminismos contemporâneos.
\end{abstract}

Palavras-chave: Aborto. Quadrinhos. Fabiane Langona. Feminismo.

\section{The defense of voluntary termination of pregnancy in the "Abortinho" cartoons by Fabiane Langona (2015-2017)}

\begin{abstract}
The article deals with how the defense of voluntary termination of pregnancy was a theme embraced by contemporary artists, cartoonists and cartoonists who are attuned to feminist demands, focusing on the series "Dicas do Abortinho", created by cartoonist Fabiane Langona. In the first part of the text, I present briefly three specific works that, with different approaches, discuss taboos, myths and the risks inherent in the practice of clandestine abortion: the autobiographical comic book narrative drawn by cartoonist Cynthia B, published in Piauí magazine, in 2014; the graphic novel produced in 2015 by artist Leah Hayes; and the graphic report, written in 2016 by journalist Joyce Gomes and comic artist Helô D'Angelo, author of the drawings. In the second part, I specifically analyze the character "Abortinho", highlighting the visual and discursive strategies employed by the cartoonist to treat this theme as a social and political problem, although it has generated significant hostility. between readers and readers. I understand that the reaction to the Abortinho series was less due to the visual impact that the series has on its readers, than to the density that the abortion theme carries, after all the defense of the rights to the body and the liberation of abortion are the biggest challenges. faced by contemporary feminisms.
\end{abstract}

Keywords: Abortion. Comics. Fabiane Langona. Feminism. 
Em 17 de março de 2015, o site Lugar de Mulher' publicou o depoimento da cartunista Fabiane ${ }^{2}$ sobre a experiência de ser uma mulher cartunista no mercado de quadrinhos humorísticos, historicamente um "território de machos", como a autora qualifica no próprio texto. Com o título "Uma Mulher Cartunista? Explique-se sobre isso!", a artista relata como começou sua relação com os quadrinhos, a passagem da condição de simples leitora para a de desenhista, pontuando as dificuldades encontradas em virtude da misoginia explícita de artistas, produtores e parte dos leitores dos quadrinhos humorísticos, assim como a luta interna travada para afastar sua produção do nicho "quadrinhos de mulherzinha”.

Fabiane discorre também o seu processo de emancipação autoral, quando decidiu usar a sua experiência como mulher para produzir os conteúdos de suas histórias sem se preocupar com qualificações externas:

[...] de propósito, passei a dar vazão ao que tanto me negava: ser, sem pânico, minha própria fonte em se tratando de humor com referências ao taxativo e binário universo feminino, - principalmente nas mentiras bobas que se apregoam em nome do mesmo - no que de mais grotesco e ridículo eu conseguiria enxergar e transpor. Usar minha vivência como mulher pra justamente transgredir a clássica e vilipendiosa representação humorística do feminino - fortemente baseada em loiras e ou donas de casa traídas e revoltadas e ou motoristas ruins - pra focar em questões reais. Reais na minha experiência de mulher comum. Desenhei os maiores peitolões simbólicos que consegui e acabei seduzida pela minha nova regra: produzir o que quisesse sem me sentir acuada. (LANGONA, 2015)

O depoimento encerra com a artista expondo o que inspira/motiva o seu trabalho e sua compreensão pessoal sobre o significado de produzir quadrinhos humorísticos: "O humor é a minha forma de fazer uma leitura da opressão que

\footnotetext{
1 LANGONA, Fabiane Bento A. Uma mulher cartunista? Explique-se sobre isso. Lugar de mulher é onde ela quiser. São Paulo. 17 mar. 2015. Disponível em: http://lugardemulher.com.br/ umamulher-cartunista-explique-se-sobre-isso/. Acesso em: 04 jan. 2018

2 Premiada em 2012 na categoria "Melhor Publicac,ão de Humor" do Trofeu HQ MIX, a gaúcha Fabiane Langona foi assistente de redac,ão e arte-finalista da revista MAD no Brasil entre os anos de 2005-2008. Publicou seus trabalhos no Jornal do Brasil (2005), Jornal do Comércio (POA) (2006-2007), Diário de Pernambuco (2006-2008), Zero Hora (2006-2009), O Estado de São Paulo (2010), Folha de São Paulo (2007-2015), além de revistas nacionais e internacionais. Participou de 16 exposic,ões, sendo três individuais e as demais coletivas, e tem dois livros publicados: Uma patada com carinho. As histórias pesadas da Elefoa Cor-de-Rosa e Algumas mulheres do mundo. Desde outubro de 2017 é cartunista fixa da sec,ão de quadrinhos da Folha de São Paulo
} 
sofremos, tanto da sociedade, como de nós mesmas [...] As mulheres que tento representar nos meus cartuns, são todas parte de mim." (LANGONA, 2015)

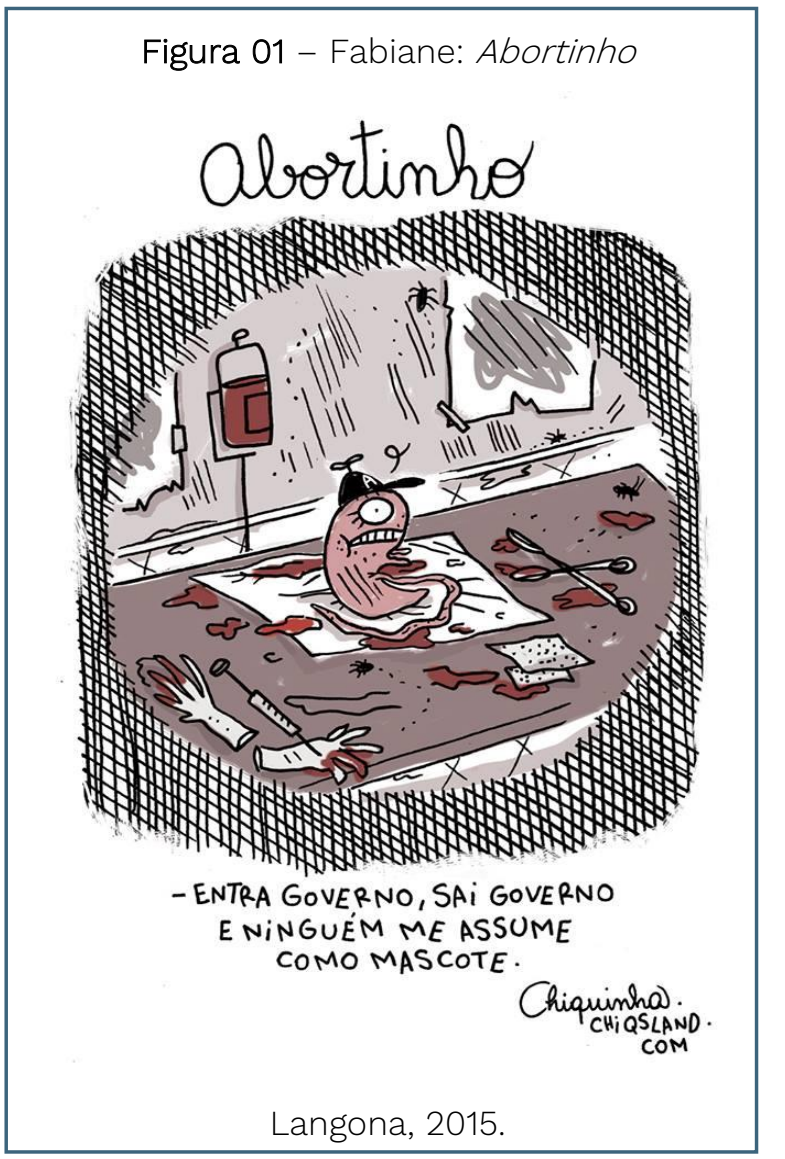

Dos cinco cartuns que ilustram o depoimento, apenas este que reproduzo ao lado era inédito. Foi a estreia, nada discreta, mas bem apropriada, de Abortinho, um feto abortado que, ainda na sala de cirurgia, questiona e tece críticas contundentes aos políticos, instituições e órgãos públicos pelo moralismo e ausência de ethos público na discussão que vem sendo desenvolvida sobre a legalização da interrupção voluntária da gravidez.

O cartum foi divulgado na mesma época em que tramitava o Projeto de Lei 5069, que trata da atenção às vítimas de abuso sexual e que propôs alterações a Lei 12.845, que dispõe sobre o atendimento integral e obrigatório de pessoas em situação de violência sexual ${ }^{3}$. O personagem Abortinho, assim como a temática que ele representa, gerou muita polêmica nas redes sociais da artista, sendo criticado até por pessoas defensoras da legalização da interrupção voluntária da gravidez por entenderem que o cartum apresenta uma "excessiva agressividade" no seu conteúdo, desde a forma do personagem até os seus enunciados.

Essa não foi a primeira vez que uma cartunista mulher utilizou seu trabalho para defender a interrupção voluntária da gravidez. É o que nos mostra a própria Fabiane, quando disponibilizou em sua página do facebook a imagem e o link de acesso ao quadrinho Abortion Eve, criado por Chin Lyvely e Joyce Sutton.

\footnotetext{
Na terceira parte deste artigo, quando analiso o personagem Abortinho, apresento $\mathrm{O} L$ 5069/2013.
} 
Publicado em 1973 e considerado pioneiro na abordagem integral do tema, esse comic book apresenta personagens mulheres de diferentes idades e raças discutindo - por vezes de forma dramática, mas sempre de modo bastante didático - não apenas a decisão de fazer ou não o aborto, mas o que buscar nos hospitais, como é realizado e os efeitos do procedimento, entre outras questões.

No artigo Aborto nas HQ de Heróis, Franco e Marino (2016) assinalam que o tema esteve presente em publicações feministas em quadrinhos dos anos 1970, como It ain't me babe, a primeira HQ feita exclusivamente por mulheres e que originou a antologia Wimmen's Comix (1972-1992), em que eram abordadas pautas feministas como o tema do aborto e da sexualidade.

Um aspecto interessante apresentado por Franco e Marino é que o aborto foi tematizado em maior escala nos quadrinhos independentes, como os selos Vertigo, Valiant e Dark Horse, ao contrário dos quadrinhos mainstream, especificamente a Marvel e DC. Aliás, na análise de como o tema é tratado nas histórias da Marvel e DC, as autoras destacam que, na maior parte das vezes, o aborto aparece como espontâneo ou um acidente, tornando-se, desse modo, um recurso narrativo dramático. Para as autoras, com isso parte-se do pressuposto de que a gravidez fora sempre desejada pela mulher e o aborto não seria, portanto, uma escolha das personagens. Ainda assim, as autoras conseguem selecionar alguns quadrinhos, publicados pela DC e Marvel em que as personagens tomam a decisão de fazer o aborto, todos publicados entre as décadas de 1990 e 2010.

Não encontrei quadrinhos, cartuns ou charges produzidos por artistas brasileiras que tratassem desse tema entre as décadas de 1960 e 1990, embora nessa época se destacassem publicações feministas como Brasil Mulher (19751980), Nós Mulheres (1976-1978) e Mulherio (1981-1987). Segundo Crescêncio, o tema ocupou pouco espaço nas páginas nesses periódicos em função tanto do tabu que envolve a prática, como da relação que os movimentos de esquerda mantinham com a Igreja.

Em suas palavras: 
Em termos de humor gráfico, por exemplo, os periódicos brasileiros feministas, pelo menos os números a que tive acesso, tratavam muito sutilmente o tema aborto e mesmo em relac,ão à produção textual a questão era tratada com muito tato e de maneira pouco frequente. Nos jornais feministas brasileiros, especialmente Brasil Mulher e Nós Mulheres, a abordagem era de denúncia sobre mortes, raramente discutia-se o aborto como um direito antes da década de 1980. (CRESCÊNCIO, 2016, p. 164)

Mesmo no Mulherio, que mostrou uma disposição diferente do Brasil Mulher e do Nós Mulheres na abordagem mais direta desse tema, tendo, inclusive, uma edição específica em 1987 sobre aborto, não encontrei charge, cartum ou quadrinho sobre o tema. Além das duas motivações mencionadas acima, Crescêncio entende que:

aborto e violência contra as mulheres, talvez, sejam os dois temas mais delicados para serem tratados com humor. Tal afirmac,ão não é baseada apenas em uma impressão, mas no fato que o tema da violência doméstica foi problematizado de maneira direta apenas uma vez em uma charge na publicac,ão boliviana La Escoba em 1986 e o aborto em uma tira do argentino Persona, também em 1986. (CRESCÊNCIO, 2016, p. 243)

Atualmente, dada a existência de múltiplas plataformas digitais (blogs, sites, Tumblr etc.), além dos meios tradicionais como jornais e revistas impressos, existe um número expressivo de projetos gráficos sobre o tema, que se materializam em forma de quadrinhos, cartuns ou charges. Essa constatação, junto com a polêmica que envolveu a publicação dos cartuns de Fabiane tanto em sua página pessoal do facebook, quanto na entrevista da revista AzMina, me leva a concordar com as premissas de Crescêncio: mesmo quando foi tematizado por artistas que se dedicam ao humor gráfico, como Fabiane, seja em forma de quadrinhos, cartuns ou charges, o aborto é tratado ora de forma didática, ora de denúncia ou ainda como uma demanda pública, ou seja, sempre de forma séria e densa.

Neste artigo, considerando a pluralidade dos meios e formas empregados para enfocar o tema, optei por realizar duas etapas de análise: inicialmente, apresentar algumas publicações existentes sobre o tema. Dado o número significativo de publicações existentes, apresentarei de forma breve três trabalhos pontuais que, com abordagens distintas, discutem o tema: a narrativa 
autobiográfica em forma de HQ desenhada pela cartunista Cynthia B., publicada na revista Piauí, em 2014; o romance gráfico produzido em 2015, pela artista Leah Hayes, publicado em forma de livro; e a reportagem gráfica, escrita em 2016 pela jornalista Joyce Gomes, com os desenhos da quadrinista Helô D’Angelo, que também participou da escrita ${ }^{4}$.

Com a apresentação sucinta desses três trabalhos, pretendo apontar os aspectos mais gerais que envolvem tais publicações, como autoria, o veículo de publicação, a narrativa e o formato eleito. O objetivo específico é demonstrar que dada a importância política desse tema, ele foi abraçado de forma plural por artistas, cartunistas e quadrinistas contemporâneas que se mostram sintonizadas com as demandas feministas. A partir dessa apresentação, me debruçarei sobre a abordagem feita por Fabiane na série "Abortinho" e "dicas do Abortinho".

Meu interesse precípuo neste artigo será, pois, examinar os recursos visuais empregados pela cartunista para tratar desse tema como um problema social e político, ainda que tenha gerado uma significativa hostilidade entre leitores e leitoras. Entendo que a reação à série "Abortinho" se deu tanto pelo do impacto visual produzido sobre seus leitorxs, quanto pela densidade que o tema "aborto" carrega, afinal a defesa dos direitos ao corpo e a liberação do aborto consistem nos maiores desafios enfrentados pelos feminismos contemporâneos. Desafio que se coloca tanto no interior dos embates travados dentro do próprio movimento feminista, como com setores da esquerda, que por muito tempo tratou o assunto a partir de sua relevância ou não no interior do debate político mais amplo, além da discussão mais abrangente e intensa estabelecida com a Igreja Católica e o Estado, que tratam essa questão a partir de uma mescla de critérios legais e morais.

\footnotetext{
${ }^{4}$ Infelizmente, não foi possível obter dados sobre a repercussão desses três projetos gráficos, ainda que tenha encontrado algumas entrevistas com as referidas artistas abordando esses trabalhos específicos. Admito que seria profícuo para o artigo, e para sustentar as premissas que apresento, poder dispor desse dado pontual.
} 
Autobiografia, Romance e Reportagem Gráfica: o aborto em diferentes narrativas visuais

Os projetos gráficos selecionados para este artigo se caracterizam por duas opções narrativas: dois têm um caráter mais didático, fundamentados em artigos, entrevistas e estudos desenvolvidos por grupos ou profissionais especializados na temática; um trata-se de uma escrita de si, nos termos propostos por Margareth Rago (2013), que prescinde do caráter mais didático e aposta no compartilhamento de experiências, anseios e angústias vividos por quem precisou fazer um aborto. No entanto, todos expressam o interesse comum de dissipar tabus, mitos, dúvidas e mentiras que envolvem todo processo: desde a descoberta da gravidez e a decisão de abortar até a realização do procedimento em si.

Ao pesquisar sobre os trabalhos de Cynthia Bonacossa ${ }^{5}$, que assina como Cynthia B., chamou-me a atenção o pouco destaque dado à HQ "Meu Aborto em Quadrinhos", publicada na edição 99, de dezembro de 2014, da revista Piauí. Trata-se de uma história curta, com apenas cinco páginas, que narra, em estilo autobiográfico, a própria experiência da quadrinista quando realizou um aborto. Segundo a artista, a proposta da publicação dessa história foi bem acolhida tanto pela revista, como pelos leitores, algo que the causou surpresa. Em entrevista à revista Risca!, Cynthia explica a opção por relatar a própria experiência de realizar um aborto: "[...] fiz autobiográfica por querer botar minha cara a tapa. Também por ser um assunto importante. Quis relatar a experiência de alguém que passou por isso, deixando claro que era real." (BONACOSSA, 2015, p. 50).

Seu estilo se destaca pela forte influência noir, um chiaroscuro bem empregado, atmosfera densa e ênfase nas sombras. Cada quadro tem um enquadramento diferente, com uma variação significativa de efeitos de zoom, por vezes começando a história por meio de plano de detalhes o que favorece a sua intensidade dramática, pois reforça a sensação de angústia da personagem. Também se destaca o expressivo número de quadros por página, por vezes a sobrecarregando.

\footnotetext{
${ }^{5}$ Assim como Fabiane e Pryscila Vieira, Cynthia B. ganhou popularidade no cenário dos quadrinhos após contribuir na seção Quadrinhas da Folha de São Paulo. Além da passagem pela Folha, Cynthia colaborou na Toscographics, também em parceria com Fabiane e outros cartunistas importantes, e na revista Piauí, assim como em publicações independentes.
} 

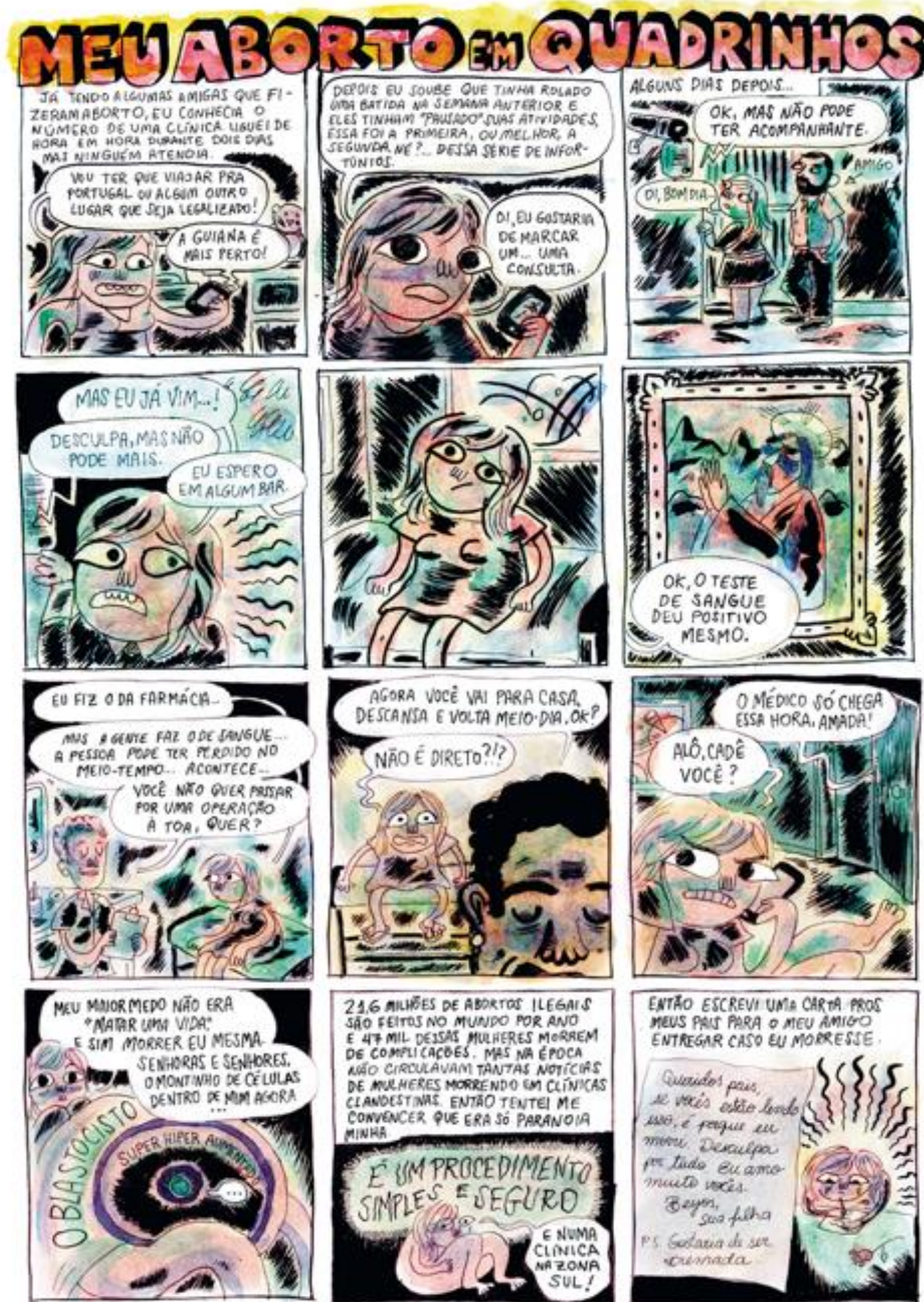

BONACOSSA, 2014. 
Impressiona o investimento da artista na expressividade dos rostos e no uso das cores para dar maior dramaticidade às cenas de dúvidas, medo ou dor. Aliás, o semblante da personagem, em diferentes momentos, é fundamental para reiterar o tom agônico da narrativa.

O roteiro pesado explora os dados coletados sobre os números relativos ao aborto sem, no entanto, aprofundá-los. Fica claro que, apesar de apresentar

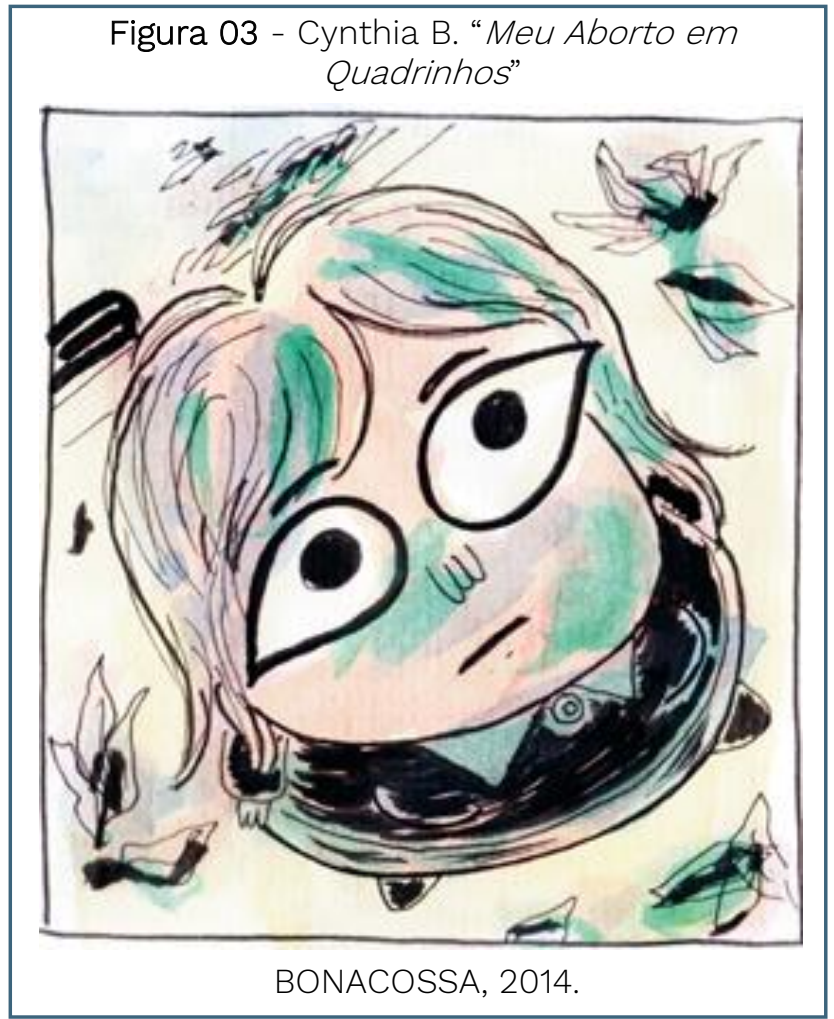
números anuais de abortos ilegais e as mortes ocasionadas, o cerne da história é o conflito subjetivo vivido entre ter o filho ou abortar, e que atravessa a personagem até o final da história, mesmo após a realização do aborto.

Esse quadrinho despertou meu interesse pela opção da artista em adotar uma narrativa autobiográfica, algo comum em suas histórias, mas não tão comum nos trabalhos que enfocam o aborto. Entretanto, o gênero autobiográfico mostra-se pertinente pois a narrativa em primeira pessoa, falando de si como se fosse de outrem, favoreceu a construção de uma visão distanciada da experiência vivida, mas com o devido aprofundamento nas emoções sentidas (medo, hesitação, angústia, solidão). Também é interessante destacar que a história prescinde de uma heroificação da personagem: não é o acontecimento (o aborto) que modela ou determina os rumos da sua vida, não há a preocupação em apresentar uma imagem da personagem no futuro e, finalmente, não há a pretensão em expor uma visão pedagógica ou educativa do fato.

Esse caráter, educativo e informativo, é o que orienta as outras duas publicações que selecionei para o artigo. Autodeclarado "manual”, o quadrinho Not Funny Ha-Ha: A Handbook for Something Hard, criado em 2015 pela artista Leah Hayes, e publicado pela editora Fantagraphics, narra, em 148 páginas, a 
história de duas mulheres, Mary, com 23 anos, e Lisa, 31 anos, de diferentes condições financeiras, culturais e familiares que decidem abortar, optando, cada uma, por procedimentos distintos: o farmacológico e o cirúrgico.

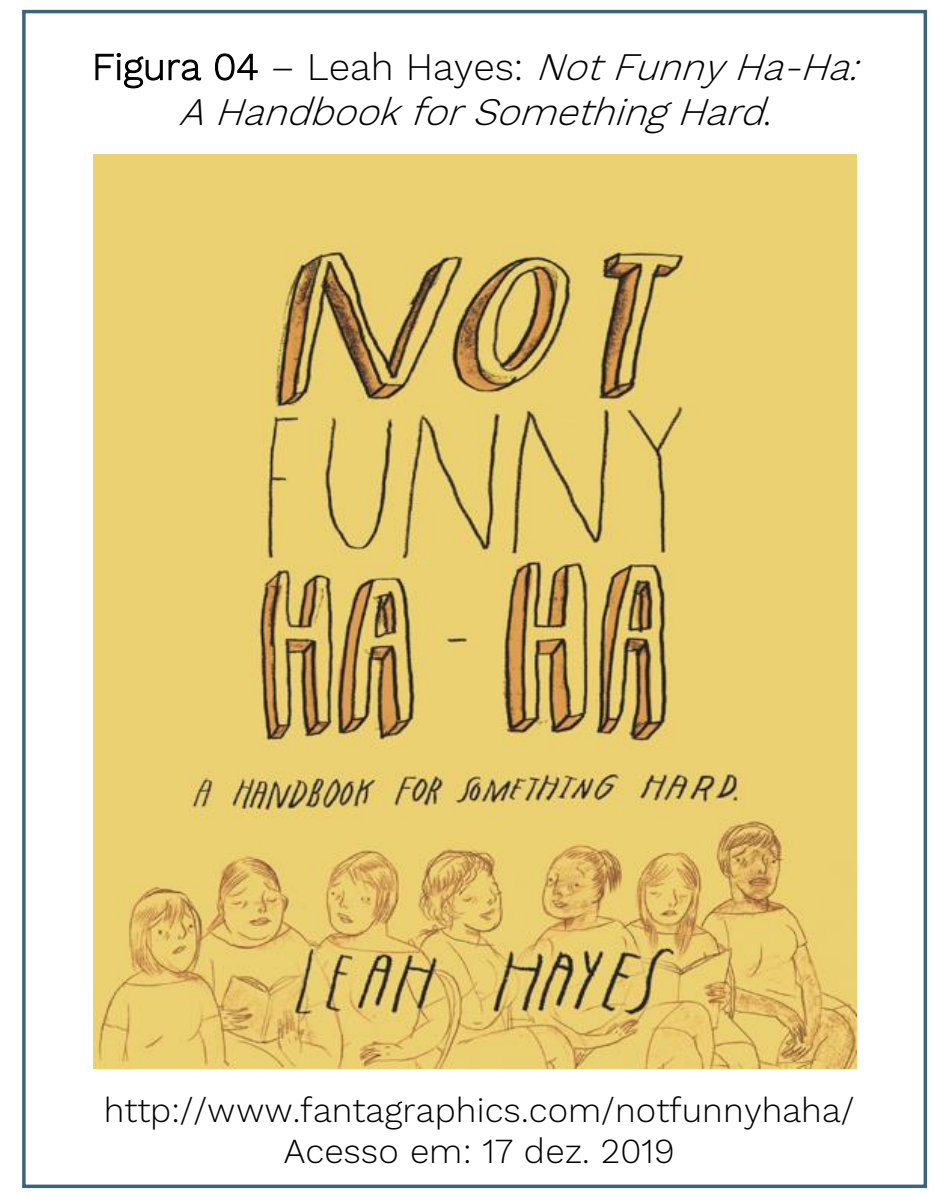

Logo nas páginas iniciais, a autora apresenta a explicação do que a motivou a escrever o manual, conferindo um caráter mais intimista à publicação, uma vez que ali ela fala por si, na primeira pessoa, e tenta se mostrar aberta ao acolhimento daquelas que realizaram abortos, sem adentrar os meandros das convicções pessoais. Em suas palavras:

Existem várias razões pelas quais decidi escrever este livro e compartilhá-lo. O tema do aborto é complicado: é colocado muito foco no certo/errado, deve/não deve, a favor/contra, escolha/não escolha, etc... o discurso político começa quase imediatamente na decisão de abortar ou não, e depois se joga descontroladamente para o final do processo. Você abortou: fez o certo ou errado? É conflituosa? Como você se considera, pró-escolha ou pró-vida? Você se arrepende, de qualquer forma? O que significa se arrepender de um aborto? O que significa se arrepender de não ter feito um aborto? O tema está carregado com ideias e questões pesadas, e muitas vezes impossíveis de responder, tanto felizes como tristes, que nos empoderam ou assustam. (HAYES, 2015). 
Tanto a artista, como a editora - na sinopse sobre o livro apresentada no site - pontuam que a preocupação central foi não apresentar um julgamento pessoal, sem prescindir de expor as implicações emocionais que envolvem esse processo.

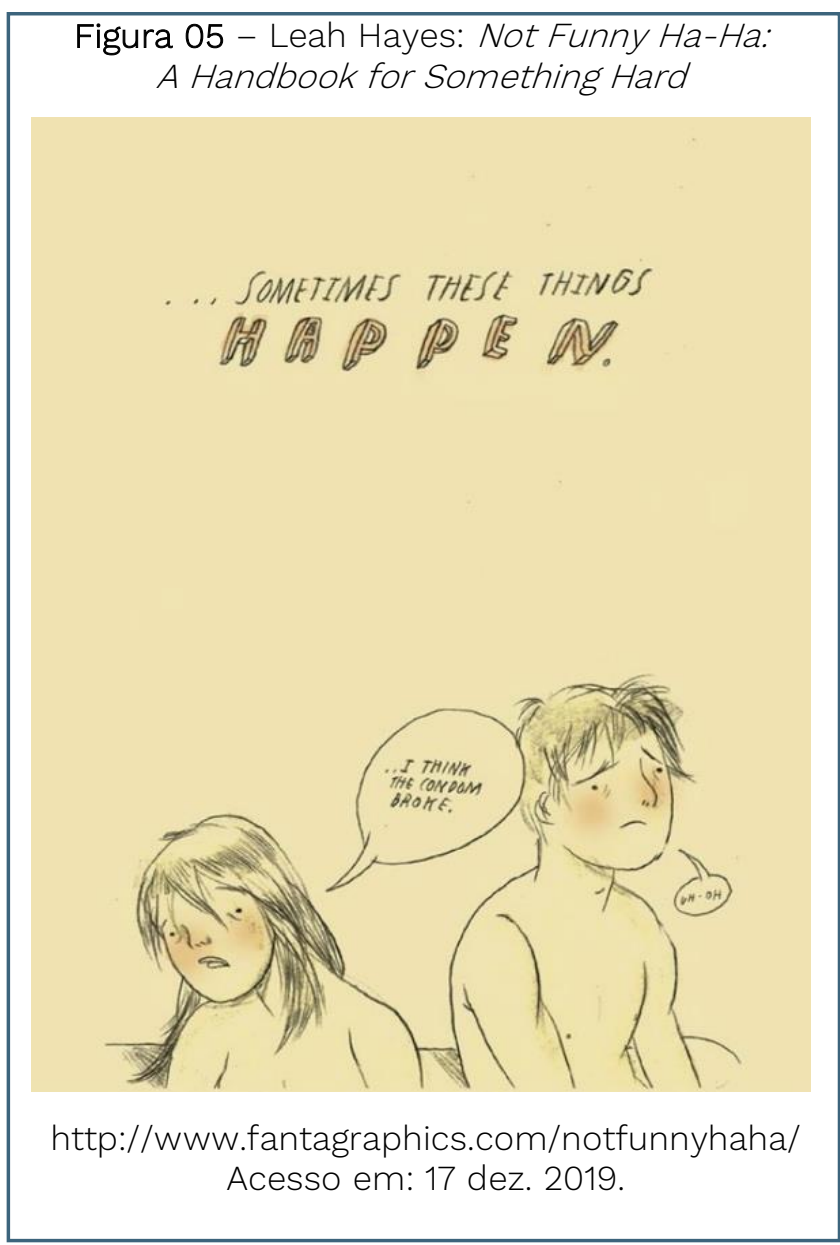

O romance gráfico foi produzido em capa dura, com páginas amarelas claras, cenários bem simples e restritos, enquadramentos que variam entre os planos geral ou médio, de forma a valorizar mais o texto que as imagens. Aliás, destacase a existência de uma narradora, para além dos diálogos entre as personagens, o que de alguma forma confere um caráter mais realista à história. A adoção dos ângulos médios permite que a leitora veja a cena de frente, focando nas expressões faciais das personagens e na voz narrativa que conta a história.

A autora explorou os aspectos subjetivos vividos (impasses, crises) após a descoberta da gravidez e a opção por realizar o aborto, demonstrando o quão traumático e solitário pode ser tal momento. Apesar da ênfase no caráter subjetivo de Lisa e Mary, em diferentes momentos a autora adota uma linguagem mais técnica para apresentar esclarecimentos específicos sobre os procedimentos em questão.

A aposta no didatismo está presente também na reportagem gráfica Quatro Marias - uma reportagem em quadrinhos sobre as realidades do aborto no Brasil (2016). Reportagem gráfica é, aliás, um estilo bastante adotado para tratar de temas que, dada as suas condições polêmicas, não encontram espaço em meios de comunicação de grande circulação. 
Figura 06 - D’Angelo; Gomes: Quatro Marias: uma reportagem em quadrinhos sobre as realidades do aborto no Brasil.

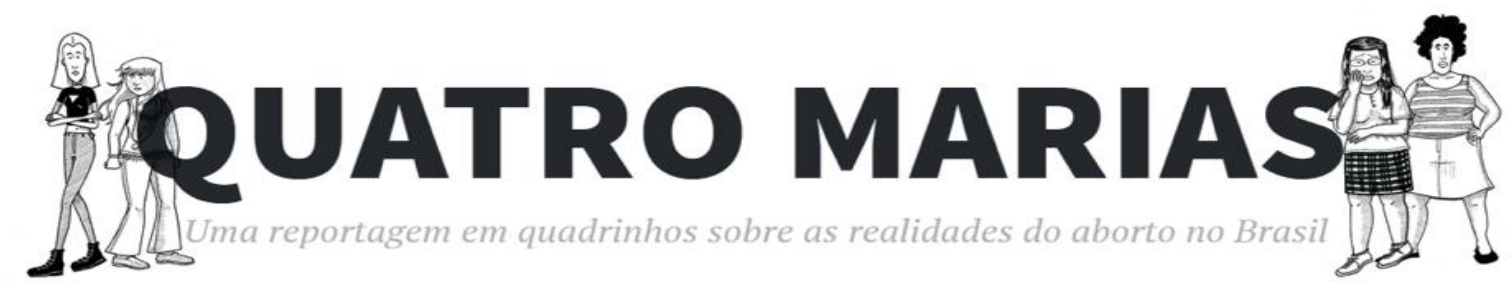

https://quatromarias.com/.

Acesso em: 17 dez. 2019.

A história foi desenhada pela quadrinista e jornalista Helô D’Angelo, que também atuou na escrita em parceria com a jornalista Joyce Gomes. Todo o material está disponível gratuitamente no site https://quatromarias.com/ onde encontram-se também informações sobre o processo de criação e as autoras.

As quatro personagens foram criadas para narrar as experiências verídicas de quatro mulheres, todas anônimas, de classes sociais, etnias, idades e contextos diferentes, que decidiram, também de formas distintas, interromper a gravidez. São histórias independentes e, por isso, podem ser lidas em qualquer ordem. As cores são usadas para reforçar os textos principais, mas a maior parte foi produzida em preto e branco, dando maior dramaticidade à narrativa.

Figura 07 - D’Angelo; Gomes: Quatro Marias: uma reportagem em quadrinhos sobre as realidades do aborto no Brasil.

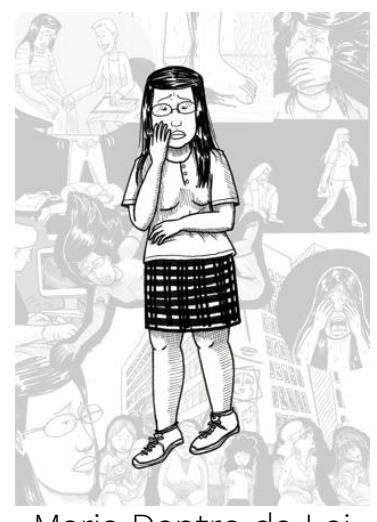

Maria Dentro da Lei

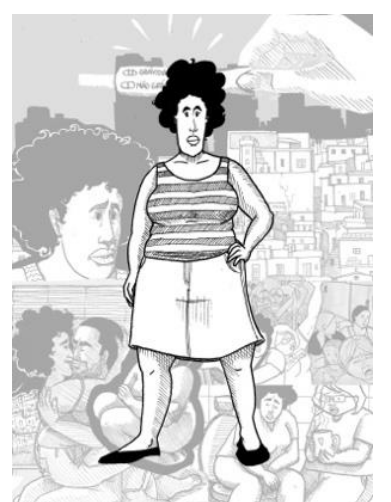

Maria Julieta

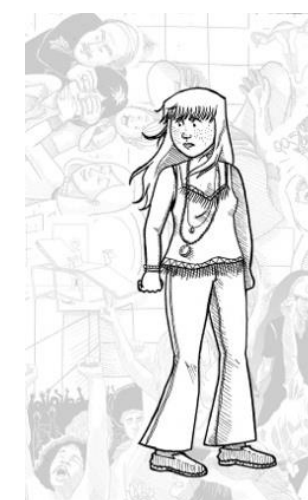

Maria Memória

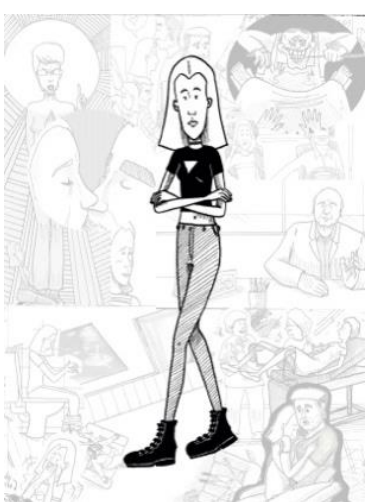

Maria Mudança

https://quatromarias.com/ Acesso em: 17 dez. 2019.

Um diferencial importante nessa HQ é a estética das personagens: Helô D’Angelo produziu mulheres comuns, sem os estereótipos tanto de mulheres 
brancas, como de mulheres negras, ambas comumente hipersexualizadas nos quadrinhos mainstream. Aliás, a fuga dos padrões representacionais de personagens femininas têm se tornado constante nas quadrinistas contemporâneas, algumas, inclusive, empregando retículas escuras para preencher a pele das personagens negras.

Assim, as quatro Marias se vestem com roupas confortáveis, algumas são corpulentas, com formas arredondadas, se aproximando, enfim, da aparência de grande parte das mulheres brasileiras.

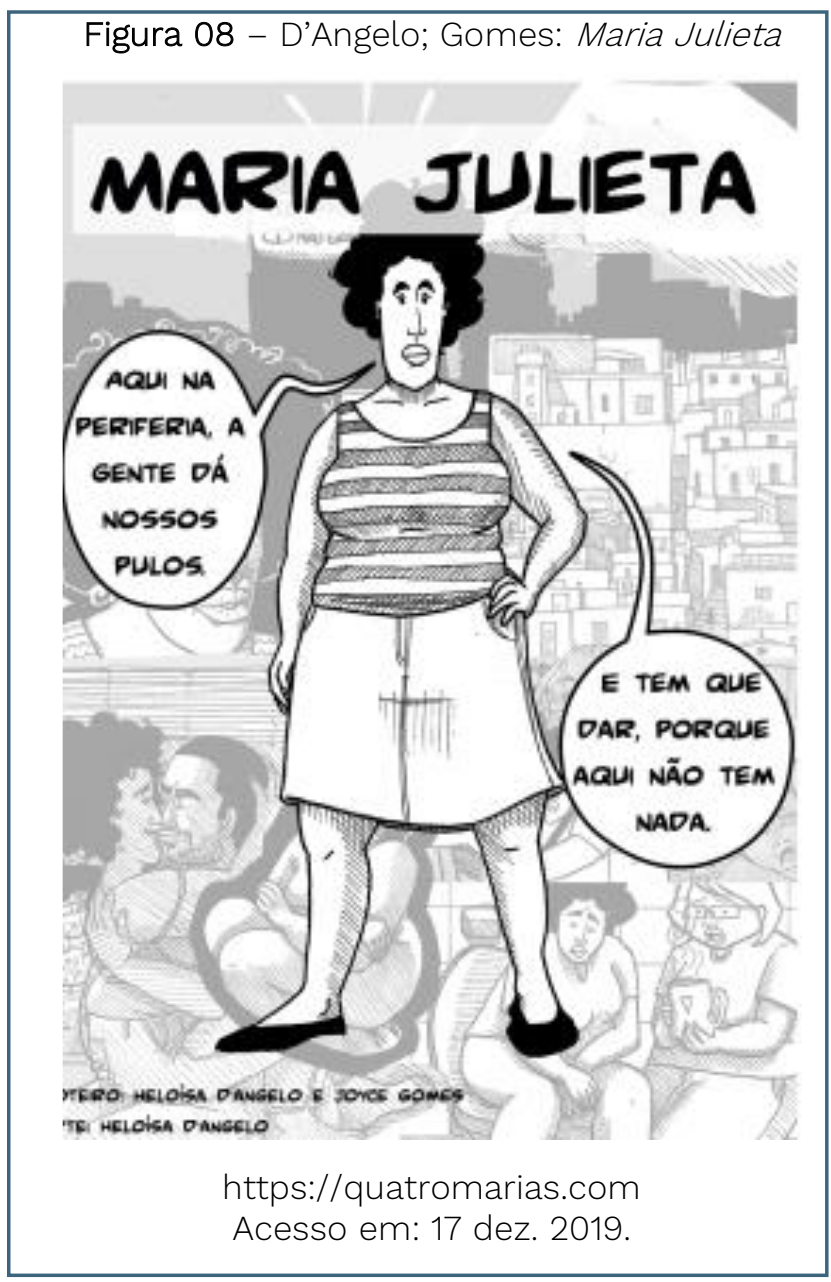

Outro diferencial é o esforço em adequar o texto ao estilo pessoal e de vida de cada personagem, tornando a leitura mais acessível apesar da abundância de termos técnicos e jurídicos. Desse modo, na história de Maria Julieta, por exemplo, há um maior uso de termos e expressões próprios do meio social ao qual a personagem pertence, assim como na história de Maria Memória, que se passa nos anos 1970, é forte o emprego de gírias da época.

Destaca-se também a preocupação em pontuar as semelhanças nos costumes e na permanência de tabus em temporalidades distintas, assim como as distinções no que se refere ao procedimento. Cada personagem engravida em condições diversas e realizaram abortos também de formas diferentes: Maria Dentro da Lei fez todo o procedimento na rede pública, sob amparo legal, já que foi vítima de estupro; Maria Julieta fez uso de medicamento abortivo; Maria Memória e Maria Mudança têm o mesmo padrão social e nível educacional, e ambas realizaram em clínicas clandestinas com procedimentos diversos, conforme a prática da época. 
No geral, as histórias empregam um texto bastante explicativo para abordar todos os passos do processo, os riscos inerentes às práticas clandestinas, e ainda contemplam questões mais amplas como os preconceitos que cercam as mulheres que engravidam sem querer, o impacto psicológico das pressões externas, assim como os tabus e o controle social sobre a sexualidade dessas mulheres. A maior parte dos quadrinhos está em preto e branco; novamente cores fortes são utilizadas para aprofundar a carga dramática das cenas e enfatizar frases ou determinadas situações.

Um aspecto específico chamou-me a atenção nos três projetos apresentados: apesar do seu conteúdo didático e da preocupação evidente em dissipar estereótipos, mitos e tabus que envolvem o aborto, não há uma defesa explícita do direito a interrupção voluntária da gravidez. Obviamente que essa premissa está subjacente a todas as propostas, mas não deixa de ser intrigante a ausência de uma enunciação direta, visual ou textual, nos quadrinhos mencionados, embora, reitero, há a ênfase sobre a necessidade do investimento em políticas públicas em saúde e educação sexual.

Parece-me que esse enfrentamento mais enfático, verbal e visual, foi a opção de Fabiane Langona, que através dos cartuns de "Abortinho" defende a interrupção voluntária da gravidez como parte do princípio democrático liberal do direito aplicado ao corpo, premissa que norteou o axioma feminista dos anos 70 "nosso corpo nos pertence" e que permanece em voga nos movimentos feministas atuais. E, exatamente, por essa opção mais "bélica”, Fabiane viveu um enfrentamento externo também mais direto e contundente.

\section{Abortinho ou dicas de como falar sobre direitos reprodutivos em cartuns}

Em outros artigos (PIRES, 2019a; PIRES, 2019b), pontuei como o estilo grotesco (BAKHTIN, 1993) se tornou uma marca e um recurso estético empregado por Fabiane para realizar uma crítica aos estereótipos e padrões heteronormativos e de gênero. 
Figura 09 - Langona: "Na luta Pelo Aborto, será que ela foi longe demais?" AZmina

\section{NA LUTA PELO ABORTO, SERÁ QUE ELA FOI LONGE DEMAIS?}

Em suas tirinhas, Chiqs quis fazer uma crítica contundente, mas acabou desagradando até mesmo quem é a favor da legalização

\section{f) 90}

https://azmina.com.br/reportagens/na-lutapelo-aborto-sera-que-ela-foi-longe-demais/ Acesso em: 17 dez. 2019.

O título da entrevista de Fabiane para a revista AzMina parece corroborar essa premissa, embora a entrevista não deixe muito claro o que seria "ir longe demais", quando o tema é aborto. No começo da conversa, as repórteres destacam a opção da artista em utilizar uma imagem "literal do aborto".

O grotesco se tornou o estilo amplamente utilizado por Fabiane, quando ela abandonou os personagens animais $^{6}$ e passou a protagonizar grande parte de suas histórias com os autorretratos, nos quais predominam o exagero, o hiperbolismo, a profusão e o excesso. Tais elementos, próprios do estilo grotesco, são estratégias empregadas pela artista para subverter e inverter os padrões sociais direcionados a gerir corpos e comportamentos femininos, definindo o que seria "apropriado" ou não. Nesse sentido, Fabiane eleva ao extremo tanto as suas feições (orelhas, olhos, boca, nariz), como seu corpo (seios excessivamente grandes, barriga proeminente, excesso de pelos disformes), como suas práticas e comportamentos.

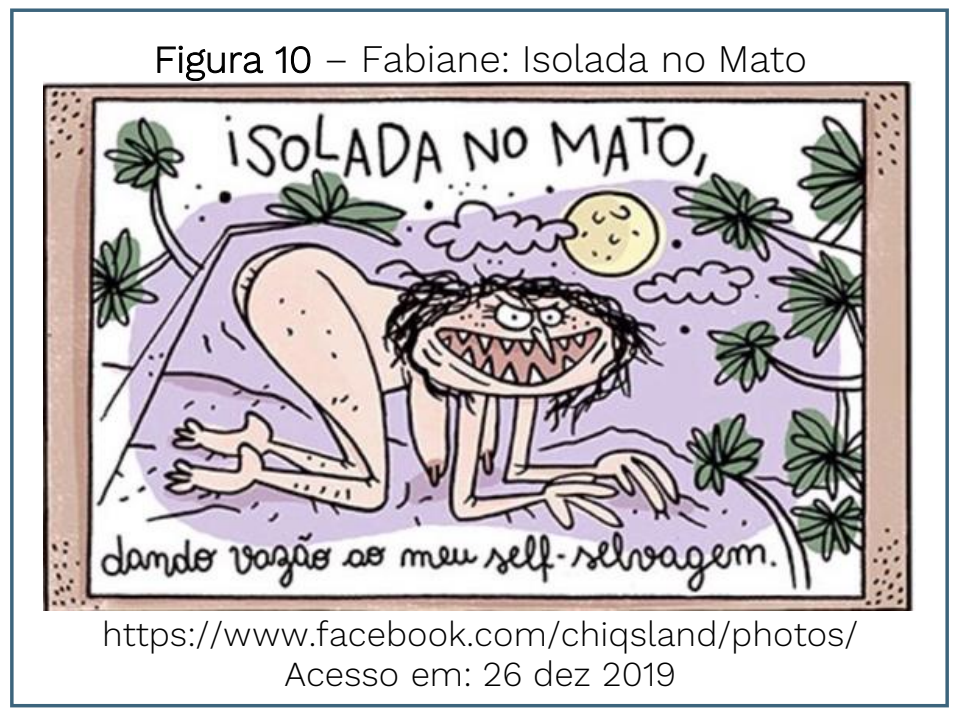

\footnotetext{
A Elefoa cor-de-rosa, a girafa Gisbelle e a ursa Janete eram as protagonistas das primeiras histórias criadas pela artista. Ver: LANGONA, Fabiane Bento. Uma patada com carinho: histórias pesadas da elefoa cor-de-rosa. São Paulo: Leya, 2011.
} 
Ao exagerar caricaturalmente o que pode ser identificado como suas características negativas, recolocando-se na realidade de forma bruta, Fabiane ridiculariza não a si mesma, mas os modelos aos quais ela se opõe. Essa estratégia, do uso do grotesco para expor bruscamente algo, foi a mesma empregada pela artista para se inserir no debate sobre o aborto, criando um personagem em que "o exagero é de um fantástico levado ao extremo, tocando a monstruosidade." (BAKHTIN, 1993, p. 267).

Enfocar no procedimento em si foi o que, na perspectiva da revista AzMina, tornou esse cartum em um dos mais polêmicos daquele ano. Não encontrei outra entrevista em que a artista falasse sobre o personagem Abortinho, embora seja citado em vários artigos que tratam do tema aborto e quadrinhos ou dos direitos reprodutivos e humor gráfico. Por isso, essa entrevista mostrou-se um importante ponto de partida para compreender os propósitos da cartunista ao produzir o personagem. Obviamente que a principal finalidade é de cunho político, embora Fabiane reafirme que nunca pretendeu se apresentar como militante, no sentido de estar associada ou afiliada a partidos, associações ou agrupamentos político-partidários.

Entretanto, essa ênfase apartidária e não militante não significou estar alheia as temáticas feministas importantes, como revela a crítica, sempre presente em seu trabalho, ao controle político e social sobre o corpo feminino, aos modos hegemônicos de compreensão de homens e de mulheres, fundados em modelos arcaicos e conservadores, e aos padrões normativos impostos as mulheres (PIRES, 2019a).

Nessa entrevista, Fabiane conta que, originalmente, o primeiro cartum do Abortinho surgiu após a Folha de São Paulo sugerir aos seus cartunistas que fizessem algo "chutando o balde sobre quaisquer temas que quisessem" como forma de demonstrar solidariedade ao Charlie Hebdo ${ }^{7}$. O material produzido seria publicado em um suplemento da Ilustrada; entretanto, o cartum de Fabiane não foi publicado no referido suplemento, segundo a artista, "por conta de problemas de última hora na gráfica” (LANGONA, 2015). Curiosamente, no primeiro post

\footnotetext{
O jornal satírico francês Charlie Hebdo sofreu um atentado em 07 de janeiro de 2015, em virtude da publicação de uma caricatura satirizando o profeta islâmico Maomé.
} 
publicado no facebook com a imagem do Abortinho, a artista apresenta uma versão distinta ao afirmar na legenda: "nunca consegui publicar oficialmente este cartum por motivo de desconfortos editoriais. pronto! e também tá aqui, na minha recente colaboração textual pro Lugar de Mulher [...]”. (LANGONA, 2015)

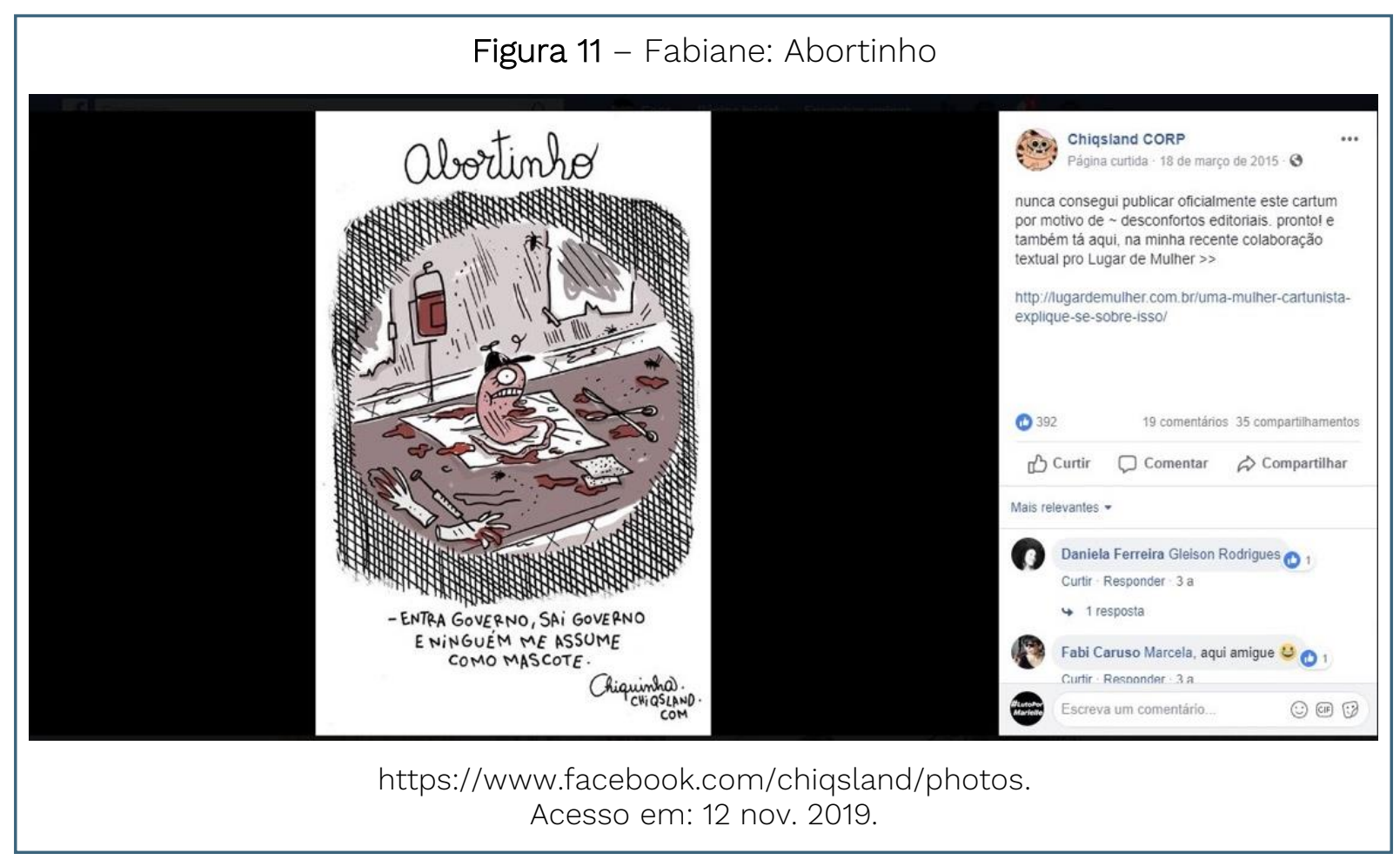

Essa assertiva indica que as primeiras restrições quanto ao cartum foram colocadas pela própria editoria da Folha, mas não foram suficientes para evitar que ela o publicasse em sua página pessoal no facebook dois meses depois. Após essa primeira publicação, em 18 de março de 2015, dois cartuns com o personagem foram publicados em sua fanpage em 22 de outubro de 2015.

Ambos se referiam às questões discutidas na Comissão de Constituição e Justiça e de Cidadania da Câmara, que aprovou em 21/10/2015 o PL 5069/2013, proposto por um dos principais representantes da bancada evangélica na Câmara dos Deputados, o então Deputado Federal Eduardo Cunha (PMDB-RJ). Rechaçado por ativistas e feministas que defendem o direito à interrupção voluntária da gravidez, o PL propôs a alteração da Lei no 12.845/2013, sancionada pela Presidenta Dilma Roussef, que estabelecia como obrigatório o atendimento às vítimas de violência sexual em todo e qualquer hospital do Sistema Único de Saúde (SUS), além de amparo médico, psicológico e social, oferta de informações sobre os direitos legais e os serviços sanitários disponíveis na rede pública e 
profilaxia da gravidez e de doenças sexualmente transmissíveis, o que envolveria o fornecimento da pílula do dia seguinte, ou a assistência pré-natal (BRASIL, 2013).

O PL modifica a compreensão sobre o que seria violência sexual, que passou de atividade sexual não consentida, para aquela que gere danos físicos e psicológicos, provados por exame de corpo de delito. Desse modo, a palavra da mulher violentada só tem legitimidade após o referido exame e apenas de posse desse laudo the será assegurado, legalmente, atendimento médico; torna proibido o uso e venda de medicamentos considerados abortivos (sem especificar quais são), deixando livre ao arbítrio dos profissionais de saúde a compreensão de quais são tais medicamentos; cria brechas para a criminalização do uso da pílula do dia seguinte, até então empregada legalmente em casos de violência sexual, ao proibir no art. 3ำ, parágrafo IV o "procedimento ou medicação, não abortivos, com eficiência precoce para prevenir gravidez resultante de estupro"; torna os profissionais de saúde acusados de "induzir ao aborto ou ajudar a gestante no procedimento" passíveis de pena de prisão de seis meses a dois anos, o mesmo para quem vender ou entregar "substância ou objeto para provocar o aborto, ressalvadas as exceções previstas na lei." (BRASIL, 2013). Caso o profissional de saúde acusado atue no serviço público de saúde ou se for médico, enfermeiro ou farmacêutico a pena aumenta de um a três anos de prisão, sendo acrescida em um terço se a gestante for menor de 18 anos $^{8}$.

A principal polêmica refere-se à definição como crime:

induzir ou instigar a gestante a praticar aborto ou ainda lhe prestar qualquer auxílio para que o faça" e "orientar ou instruir a gestante sobre como praticar aborto", exceto nos casos de "gravidez resultante de estupro, constatado em exame de corpo de delito e comunicado à autoridade policial". A pena prevista (detenção de seis meses a dois anos) aumenta quando o "crime é cometido por agente de serviço público de saúde ou por quem exerce a profissão de médico, farmacêutico ou enfermeiro". (O QUE O PL..., 2015)

O cartum que reproduzo abaixo, foi o primeiro e alude a essa proposta de modificação terminológica e procedimental de diversos artigos do Código Penal.

\footnotetext{
${ }^{8}$ Para consultar o PL na íntegra: http://bit.ly/1GINo8T.
} 


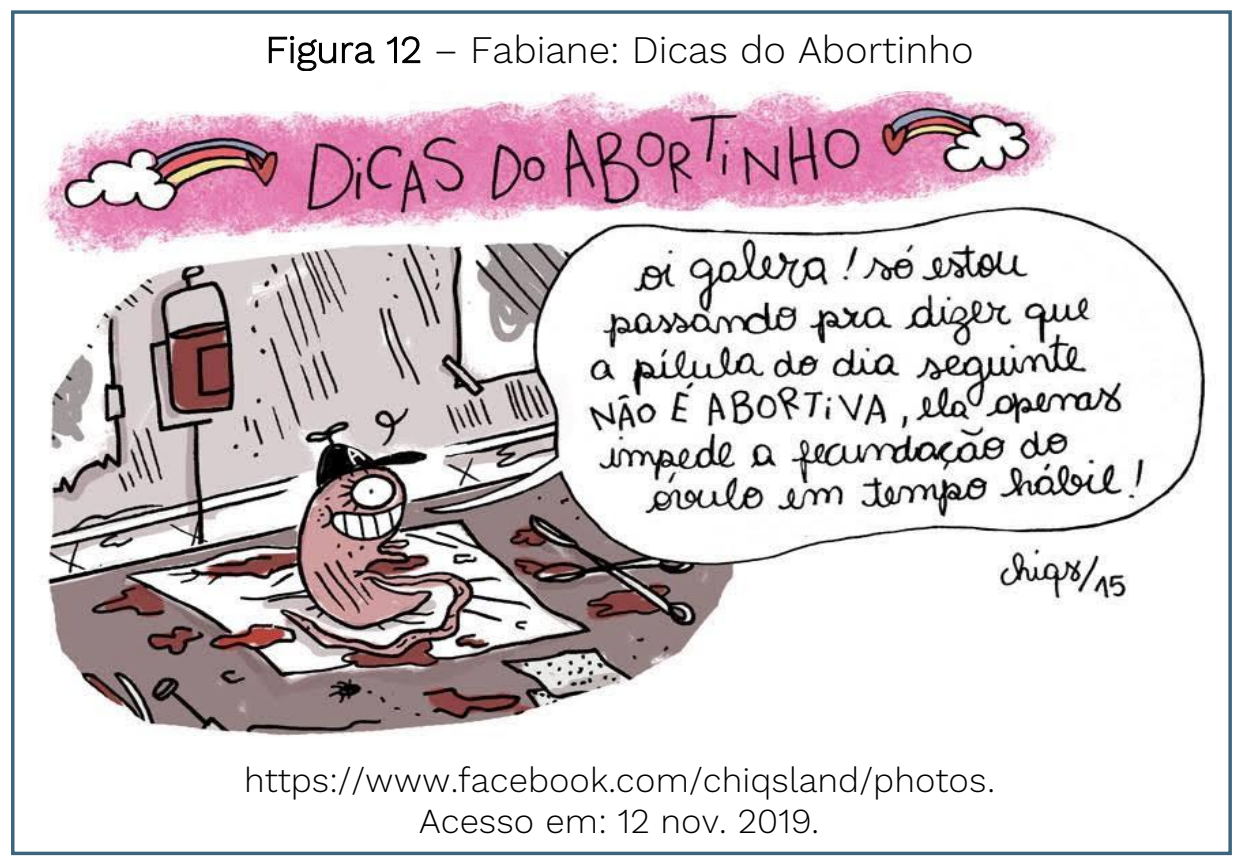

Conforme os críticos do PL, essa nova determinação torna possível a criminalização da venda da pílula em farmácias, se ela for considerada abortiva. Feministas e trabalhadores da área de saúde teceram críticas profundas a esse projeto de lei, especialmente pela substituição da garantia da "profilaxia da gravidez", ou seja, a medicamentação da pílula do dia seguinte para a vítima do estupro, por "procedimento ou medicação, não abortivos, com eficiência precoce para prevenir gravidez resultante de estupro." (BRASIL, 2013)

A alteração proposta no PL implicaria na não utilização da pílula do dia seguinte, uma vez que para muitos deputados evangélicos, como o próprio Eduardo Cunha, a pílula é um medicamento abortivo. Interpretação equivocada, uma vez que, segundo cientistas, a pílula não provoca aborto, mas atua evitando ou adiando a ovulação.

O PL acrescentou o seguinte artigo à Lei 12.845: "Nenhum profissional de saúde ou instituição, em nenhum caso, poderá ser obrigado a aconselhar, receitar ou administrar procedimento ou medicamento que considere abortivo." (BRASIL, 2013). O problema identificado nesse trecho é que o método a ser empregado pelo médico passa de um padrão estabelecido por lei para uma livre escolha do profissional que atenda a vítima de estupro. Assim, conforme suas convicções pessoais e religiosas, o profissional em questão pode se negar a medicar a paciente com a pílula do dia seguinte. 
Esse primeiro cartum foi o que gerou um debate mais acirrado entre os leitores e leitoras que ora se mostravam contrários ao personagem, ora defendiam o seu caráter crítico ${ }^{9}$.

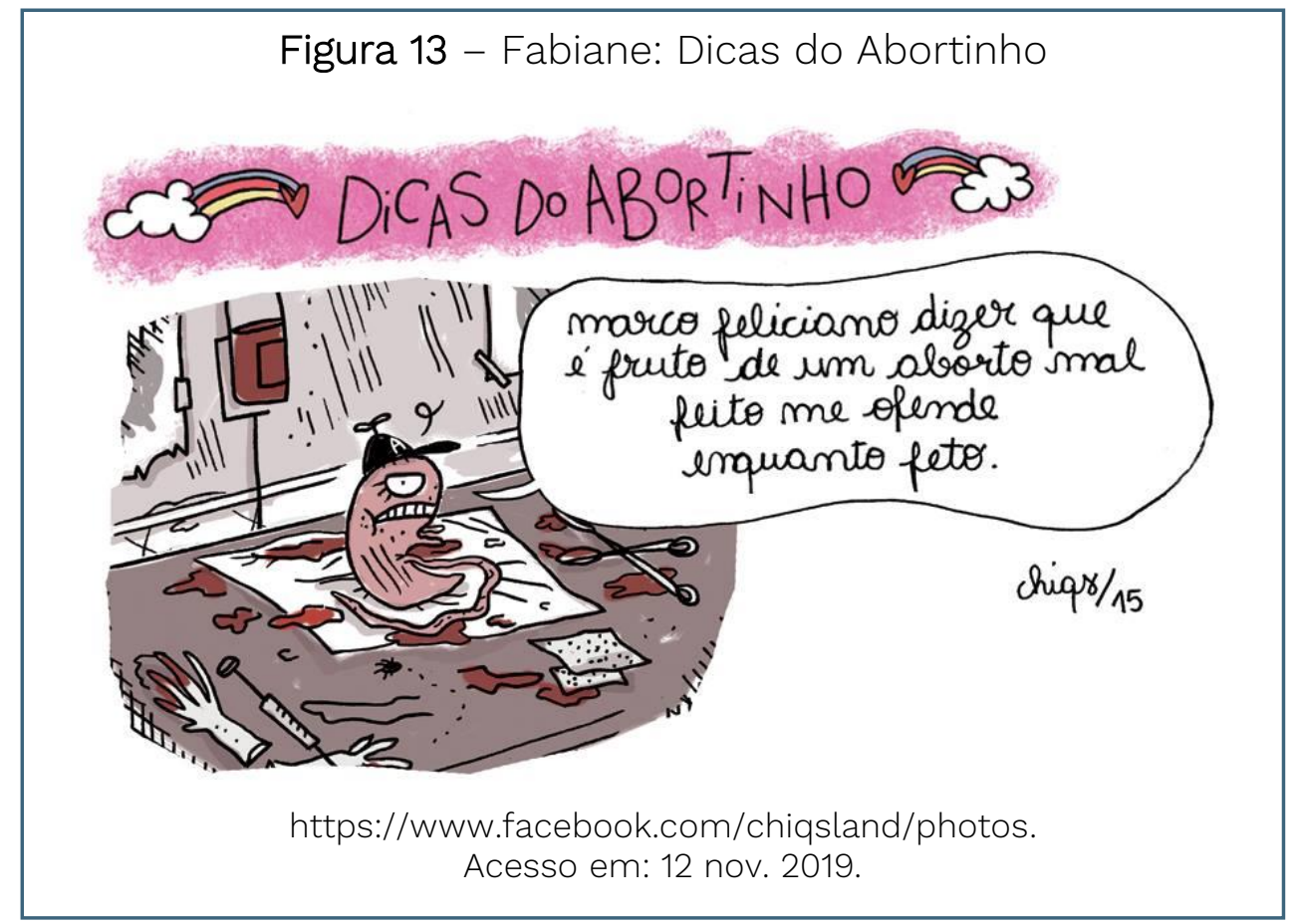

O segundo cartum, publicado também no dia 22 de outubro de 2015, menciona diretamente um dos defensores do PL, o deputado e pastor Marco Feliciano, que em entrevista a um programa no canal de “'YouTube justificou sua oposição ferrenha à interrupção voluntária da gravidez por ter, ele próprio, sobrevivido a um aborto, uma vez que sua mãe teria feito vários abortos em casa.

A partir dessa data, Fabiane publicou, ainda no mês de outubro de 2015, mais cinco cartuns com o mesmo personagem, sendo quatro com as chamadas “dicas do Abortinho" e um apenas “Abortinho”. Posteriormente, publicou mais um cartum em 03 de novembro de 2015 e mais dois seguidos em 05 de novembro de 2015, todos com o título "dicas do Abortinho".

Na entrevista que a revista AzMina fez com Fabiane ${ }^{10}$, a repórter conta que a recepção da publicação do cartum na página da revista no facebook também gerou bastante incômodo entre as leitoras e leitores, sob o argumento que "o desenho poderia ser traumático para as mulheres que já fizeram um aborto."

\footnotetext{
${ }^{9}$ Foram 261 comentários, 5 mil compartilhamentos e 4,9 mil curtidas, um número expressivo se comparado aos 12 comentários, 36 compartilhamentos e 577 curtidas do primeiro post.

Disponível em: https://azmina.com.br/reportagens/na-luta-pelo-aborto-sera-que-ela-foilonge-demais/ Acesso em: 17 dez. 2019.
} 
(RODRIGUES, 2016). Em virtude desse incômodo, a editoria da revista além de pedir desculpas publicamente, optou por tirar as imagens do ar. Do mesmo modo, antes de começar a entrevista, publicou o seguinte aviso “aliás, se você é uma delas, avisamos que a entrevista e as imagens a seguir podem provocar sensações desagradáveis." (RODRIGUES, 2016)

O desconforto que o cartum ocasionou ficou evidente quando Fabiane teve seu computador invadido e "toda a série do Abortinho, incluindo tiras inéditas, foi deletada, assim como ilustrações que ela fez para o movimento Mulheres em Luta." (RODRIGUES, 2016). O ataque sofrido por Fabiane demonstra o quão polêmico é o tema do aborto, ainda que tratado em forma de cartuns, gênero cuja seriedade e importância, em geral, são colocadas sob suspeição.

Apesar dos danos sofridos, a cartunista alcançou um dos seus objetivos primeiros quando elaborou o personagem: incomodar, chocar. Em suas palavras: “[...] Às vezes o papel da arte tem de ser esse: levantar discussões por meio de um certo choque. Me propus a me expor como artista e assumo as consequências." (RODRIGUES, 2016). Para a cartunista, uma "dose de violência" se mostra importante em determinadas condições, como quando o Estado brasileiro, embora laico, verga-se aos dogmas religiosos, tanto da Igreja Católica como dos grupos neopentecostais que se encontram representados por parlamentares que assumem abertamente a defesa de suas convicções religiosas em detrimento do que estabelece a constituição no que tange a laicidade do Estado.

A principal característica do Abortinho é o traço minimalista adotado pela artista para defini-lo. O personagem é um feto retirado ainda em formação, por isso ainda não tem o corpo e os órgãos delineados: sem braços, pernas ou qualquer outro membro, ele se define por ter apenas um olho e uma grande boca. Apesar de fisicamente incompleto, esses dois órgãos revelam tanto a sua personalidade assertiva, como seu estado de ânimo, ora inquiridor e/ou contestador, ora didático e/ou elucidativo. Isso fica evidente nos dois cartuns a seguir: no primeiro, publicado em 26 de outubro de 2015, ele assume um tom assertivo em defesa da garantia constitucional do direito de escolha, que às mulheres é cerceado quando se refere ao seu próprio corpo. 


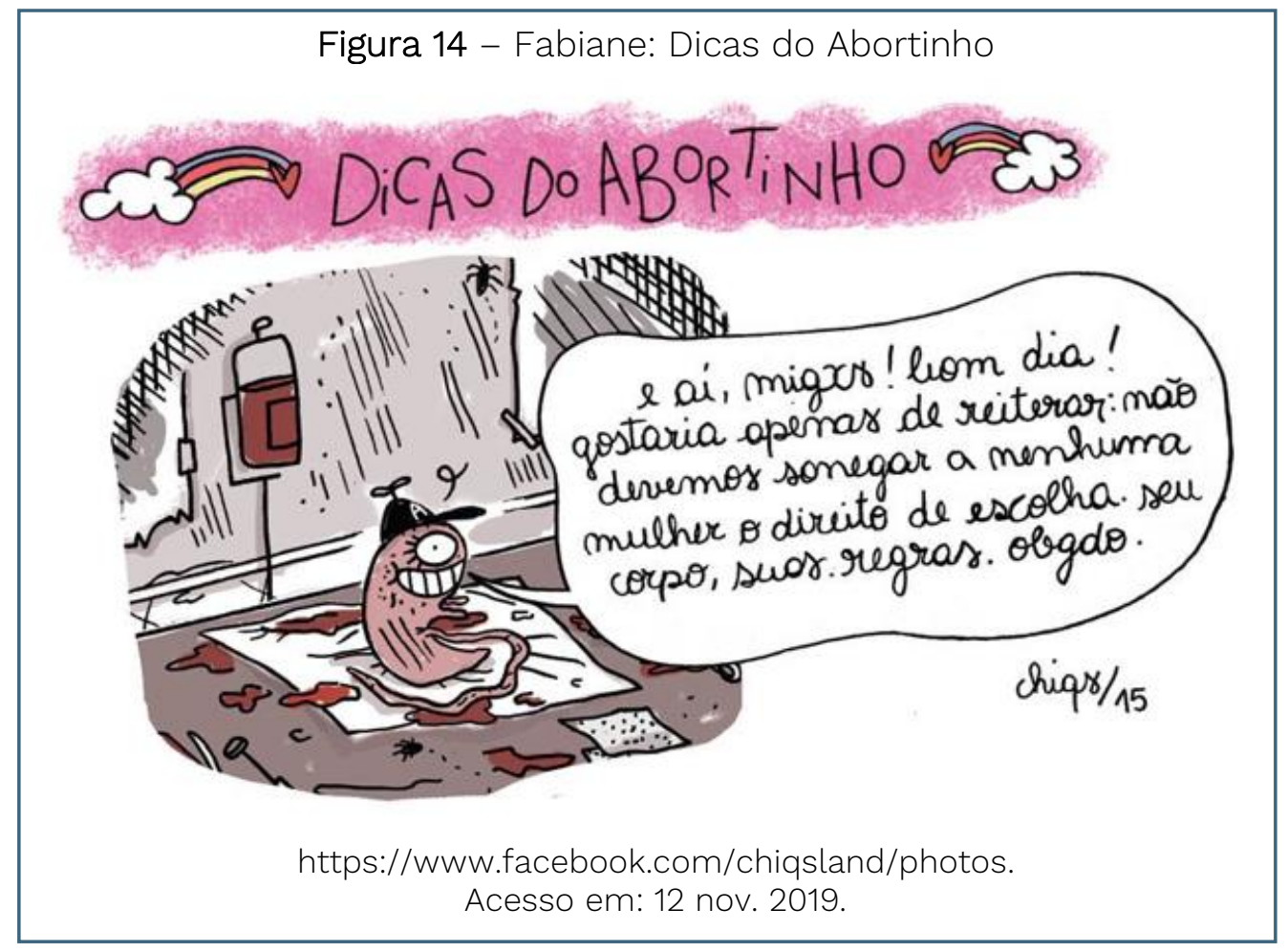

O segundo, publicado em 03 de novembro de 2015, contra-argumenta as críticas recebidas quanto a sua suposta agressividade, expondo as condições insalubres que caracterizam grande parte das clínicas clandestinas que fazem abortos. Essa representação disforme do feto, desarticula representações regularmente empregadas que recorrem a imagens de bebês já formados.

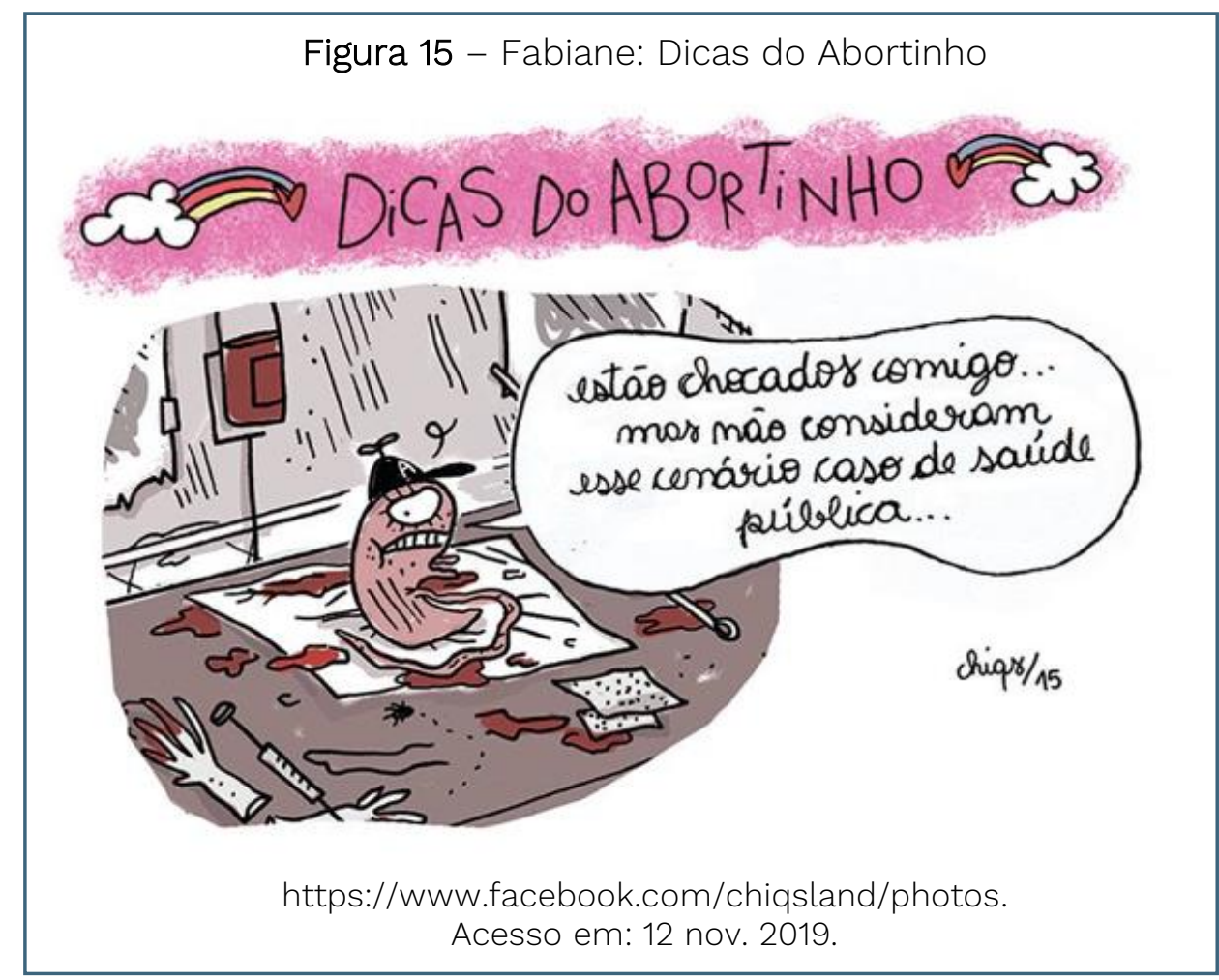


Comumente, essas representações dóceis e frágeis de bebês para se referir ao embrião são fundamentais para sobrepor o elemento afetivo ao argumento de defesa da emancipação política dos corpos femininos e da importância de se tratar desse tema como uma questão de saúde pública. Apesar do pequeno detalhe do boné, único elemento "gracioso" do personagem, estamos diante de algo impossível de se definir, amorfo, e que exatamente por ser indefinido não despertaria, teoricamente, afetos positivos.

O cenário permanece o mesmo em todas as tiras, com pequenas mudanças que conferem um certo dinamismo às histórias, como a barata que ora aparece ao lado do personagem, na primeira tira em movimento, no seu lado esquerdo, ora está em outra parte do cenário, na segunda, subindo pelo lado direito da parede.

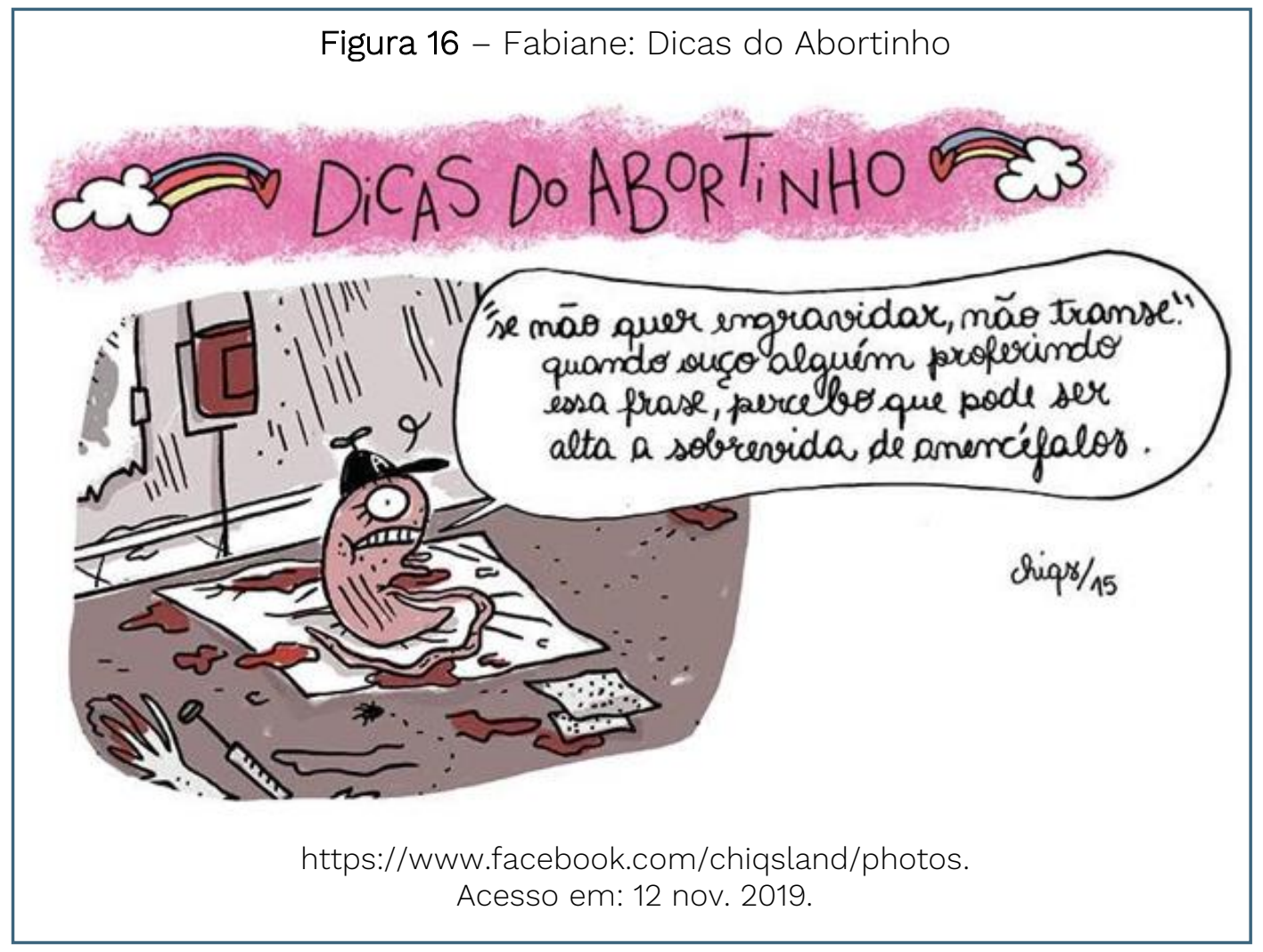

O texto irônico apresenta uma certa ingenuidade que serve para carnavalizar representantes políticos, relativizar argumentos e lugares comuns veiculados pela mídia durante o debate em torno do PL, resultando numa crítica social ferina e pontual. Por intermédio da ironia e da apropriação das enunciações 
contrárias às propostas feministas, revelam-se suas insubsistências e contradições.

Em novembro de 2015, Fabiane publicou esse que foi o último cartum da série Abortinho e que consiste numa provocação, na medida em que estabelece um paralelo entre a situação brasileira e a da índia, onde em fevereiro de 2013, foi instituída uma lei que isenta de penalização estupros cometidos por integrantes das Forças Armadas, por políticos e o estupro matrimonial, apesar de ter aumentado a pena para 20 anos de prisão nos demais casos.

Obviamente que no Brasil não dispomos de algo com esse teor, mas subentende-se que a cartunista está fazendo uma referência às dificuldades impostas ao aborto no caso das vítimas de violência sexual, sem nenhuma menção punitiva ao violentador.

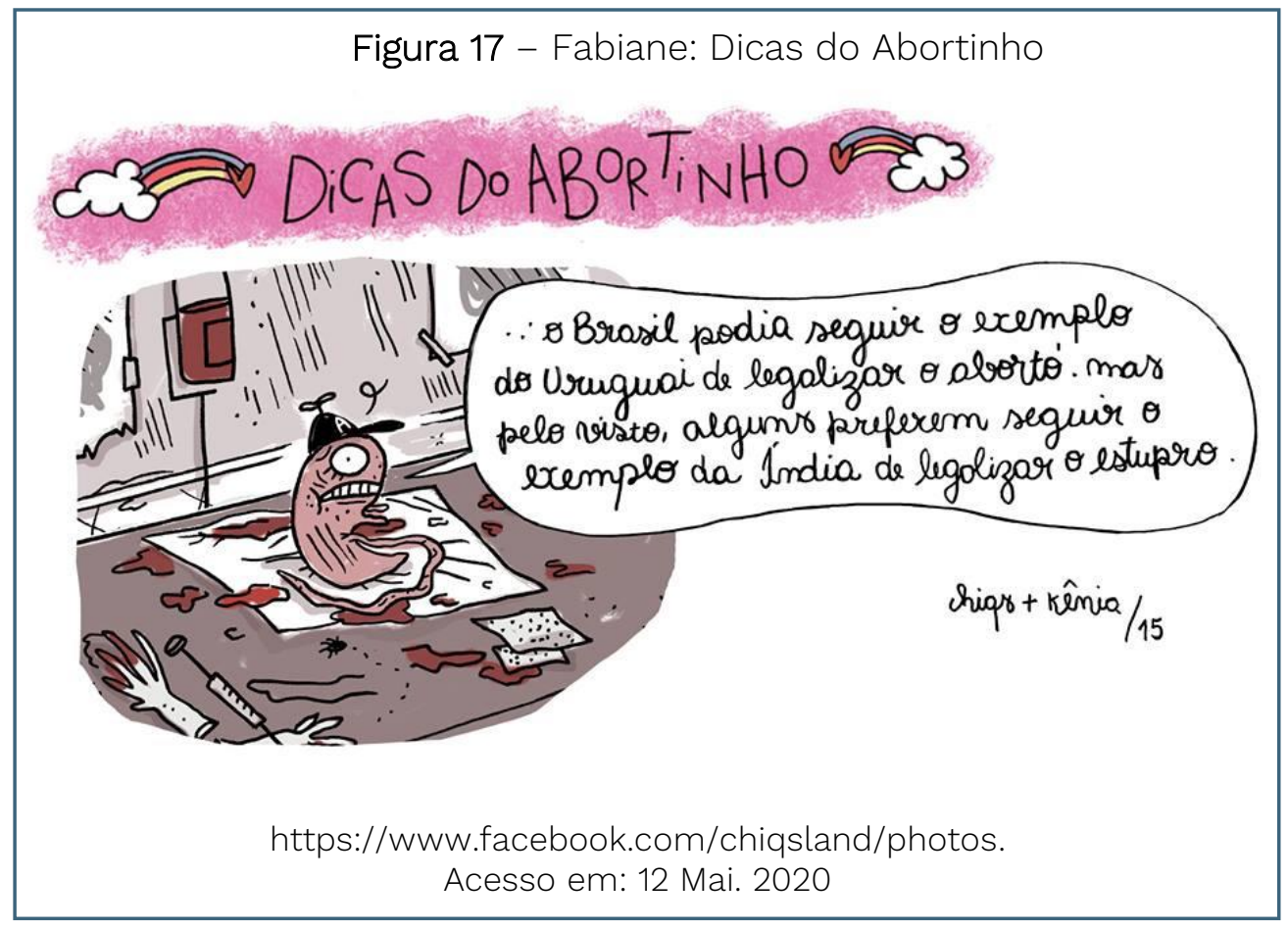

A partir de então, o personagem reapareceu de forma muito pontual em outras ocasiões. Em junho de 2016, a cartunista o recuperou para questionar a posse da nova gestora da secretaria de políticas para mulheres, deputada Fátima Pelaes (PMDB/AP) que, na ocasião, era também presidente da Frente Parlamentar Evangélica, grupo que liderou a apresentação de projetos de lei contrários à legalização do aborto ou ainda dificultando o acesso legal ao mesmo. 


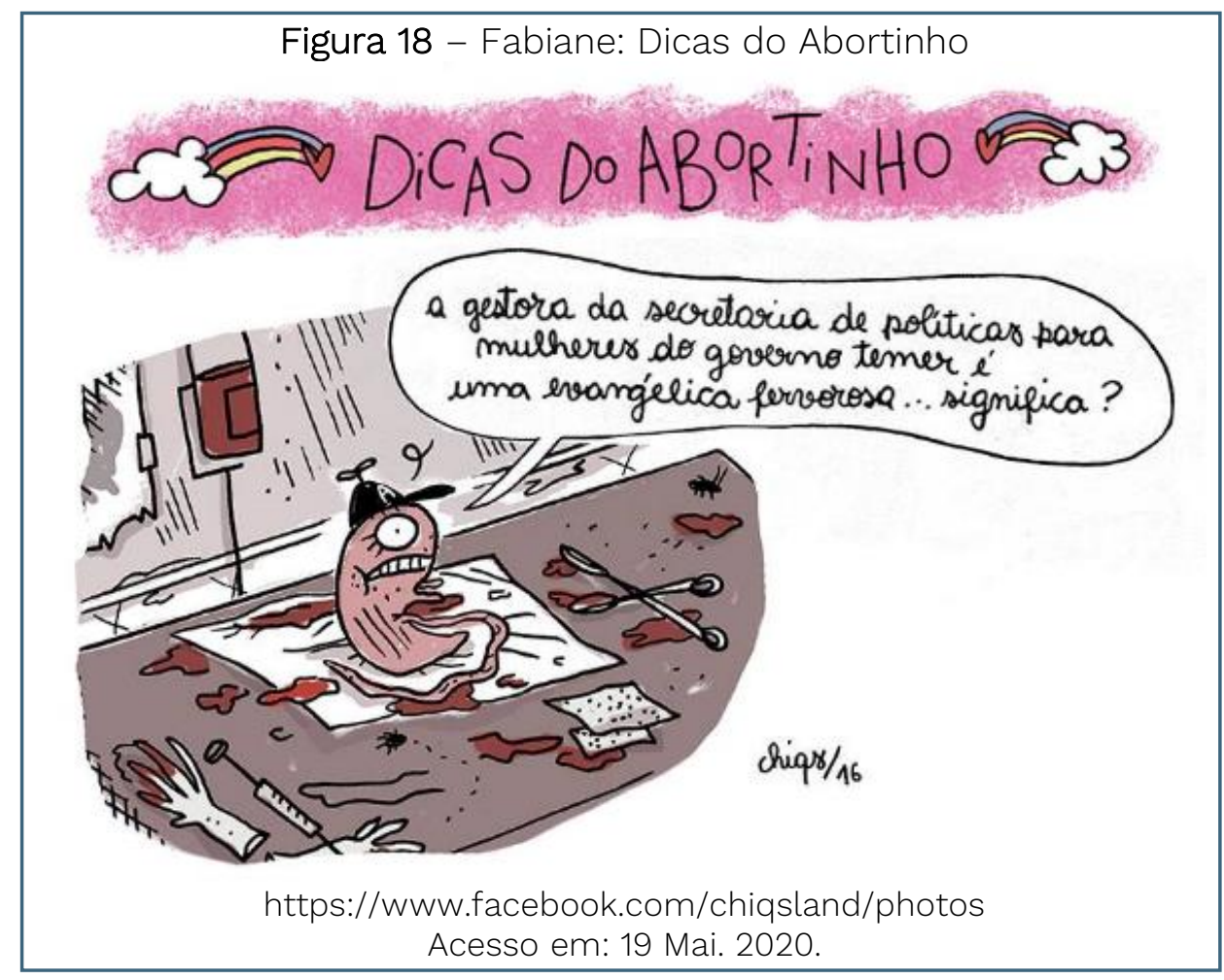

Foram poucos os comentários a essa publicação, apenas 11, e nenhum com teor agressivo, contrário ou crítico. Por fim, Abortinho reapareceu em uma série de quatro cartuns publicados entre 14 e 17 de novembro de 2017, com a legenda “is back” colocada no topo do cartum, ao lado do seu nome, e as hashtags \#contrapec181 e \#pelavidadasmulheres, colocadas no lado direito. Dessa vez, o personagem se manifestou de forma contrária à Proposta de Emenda Constitucional 181/2015 criada, originalmente, com o intuito de legislar sobre a ampliação da licença maternidade para mães de bebês prematuros, mas que após uma manobra da ala conservadora da Câmara dos Deputados, liderada pelo deputado Tadeu Mudalen (DEM/SP), inseria uma modificação do texto constitucional, que nada tinha a ver com a questão da prematuridade ${ }^{11}$.

Nessa série, identificam-se duas mudanças importantes: a primeira foi ter sido publicada na seção de cartuns da Folha de São Paulo, como parte da coluna "Viver Dói”, de Fabiane. Essa seção era compartilhada por seis cartunistas, na

\footnotetext{
${ }^{11}$ A mudança propunha a inserção da frase "desde a concepção", no inciso 3 do artigo 1o da Constituição, que aborda os princípios fundamentais da República, e no artigo 5o, que garante a igualdade de todos perante a lei. A partir dessa proposição, a Constituição impediria a realização do aborto em qualquer circunstância, inclusive em caso de gravidez resultante de estupro, de risco de morte da mulher ou, ainda, em gestação de anencéfalo, os três únicos casos permitidos por lei no Brasil. Após intenso debate e pressão de grupos nacionais e internacionais, a proposta de mudança foi retirada da PEC, que permanece sem ser votada até os dias atuais.
} 
seguinte ordem: Laerte, Caco Galhardo, Fernando Gonsales, Adão Iturrusgarai, André Dahmer, e, ao final da página, Fabiane. ${ }^{12}$ Para comentários dos leitores, a Folha de São Paulo disponibiliza o Painel do Leitor, logo nas páginas iniciais do jornal, mas não encontrei nenhuma menção ou comentário sobre o cartum. A série permaneceu sendo divulgada nas redes sociais da cartunista, dessa vez quase sem comentários.

A segunda mudança significativa foi que os dois primeiros cartuns publicados nos dias 14 e 15 de novembro, respectivamente, mantiveram 0 formato de apenas um quadro horizontal, enquanto os dois últimos apresentam uma divisão em duas partes, ambos horizontais e em plano geral, que permite ao leitor a visão de todo o ambiente onde se desenvolve a ação. Em todos permanecem os enunciados curtos, com poucas figuras de linguagem, prevalecendo a ironia como recurso discursivo principal.

Embora o cenário se mantenha o mesmo, saturado com os elementos gráficos que o caracterizam, os balões com as falas que apresentam as indagações-chaves do Abortinho, ora ocupam o mesmo espaço, ora se sobrepõem ao cenário. No cartum abaixo, o recurso da caixa alta conferiu o tom imperativo e a intensidade almejada à mensagem central da série: O DIREITO À VIDA.

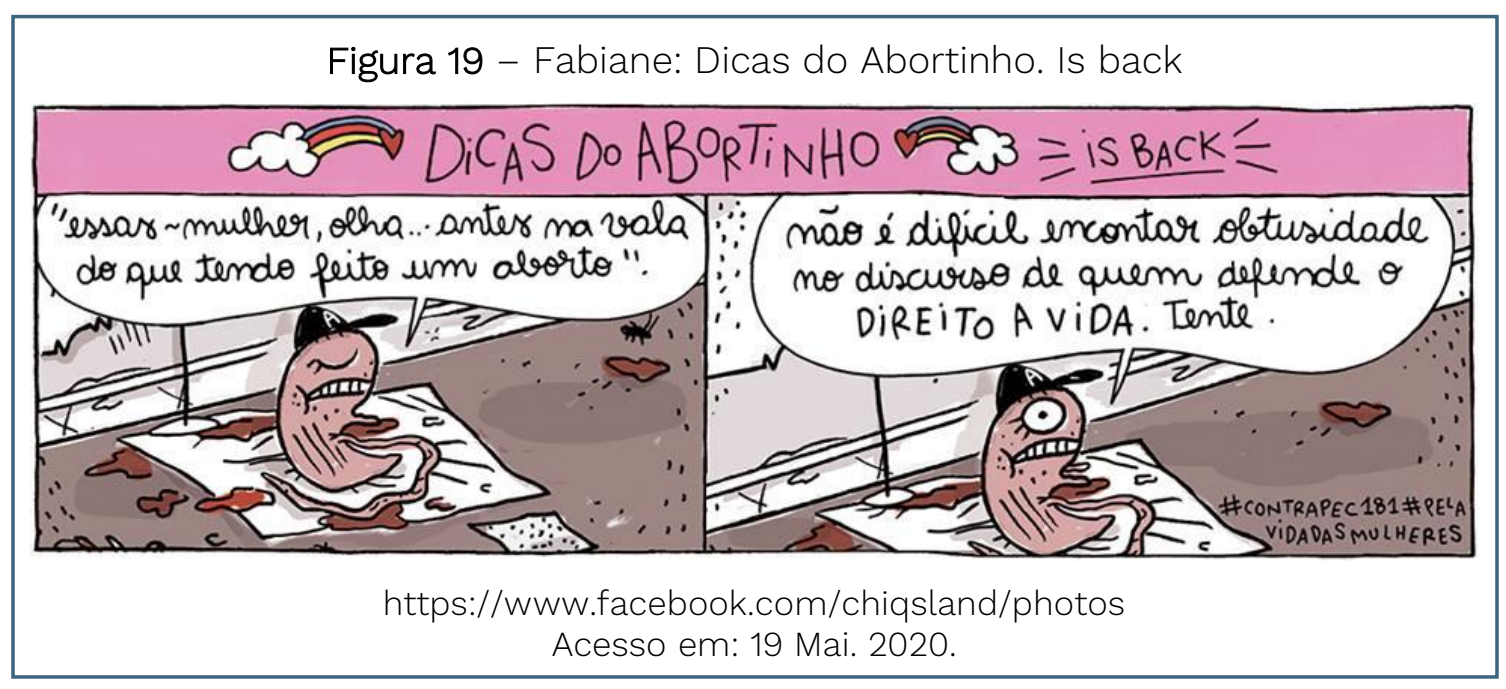

\footnotetext{
${ }^{12}$ Ressalto que não tenho elementos para afirmar ou negar com convicção que a ordem da página represente alguma forma de hierarquia entre os artistas. É com o intuito informativo que menciono essa ordem aqui.
} 
Finalmente, entendo que a junção desses recursos gráficos, em um personagem cuja característica central é o traço minimalista, foi fundamental para conferir maior densidade e expressividade ao personagem e à série, num esforço didático de aguçar a leitura crítica dos leitores e leitoras sobre o tema abordado.

\section{Abortinho e a luta pelo direito à autonomia do corpo feminino}

O debate que originou os cartuns de Abortinho teve início em 2013, quando se descortinaram as primeiras manifestações do violento retrocesso que estava por vir na política brasileira. Ao me referir a retrocesso, estou aludindo sobretudo ao crescente ataque e usurpação dos direitos políticos e sociais conquistados pelas minorias políticas (mulheres, negros, LGBTQI+, indígenas).

O controle sobre o corpo e a sexualidade das mulheres e dos grupos LGBTQI+ se mantém como matéria de especial interesse dos grupos conservadores, sendo o tema do direito à interrupção voluntária da gravidez um dos mais atacados por esses grupos. Dados apresentados em matéria feita pela revista Carta Capital mostram que no Brasil, nos últimos 70 anos, as mulheres apresentaram 36 projetos políticos relacionados ao tema, enquanto os homens foram autores de 216 (MARTINS; SILVA, 2015). A década de 2010 registrou um aumento de 44\% de propostas favoráveis à punição e à proibição do aborto, ao contrário da década de 1990, quando houve o maior número de propostas favoráveis ao direito de abortar com apenas 6\% contrárias.

Para ficarmos apenas com os números do ano de 2019, os parlamentares homens constituem $80 \%$ dos que apresentaram projetos de lei voltados ao tema. No total, foram cerca de 28 propostas mencionando a questão do aborto, sendo que 43\% defendiam a restrição do direito à interrupção voluntária da gravidez. Encontramos desde o pleito à proibição de métodos contraceptivos, considerados como "microabortivos", a argumentos como os empregados pela a deputada federal Chris Tonietto (PSL/RJ), responsável por seis propostas relacionadas à proibição do aborto: "O autor do estupro ao menos poupou a vida da mulher - se não ela não estaria grávida. Pergunta que não quer calar: é justo 
que se faça com a criança o que nem sequer o agressor ousou fazer com a mãe: matá-la?" (TONIETTO, 2019).

Esses dados breves nos ajudam a ilustrar a complexidade que envolve a temática. No Brasil, ao contrário de países como a Argentina, ainda falta um debate social amplo, que coloque em primeiro plano os direitos das mulheres e a questão da saúde pública. Prevalecem argumentos obscurantistas pautados ora nas conviç̧ões pessoais, ora em pressupostos moralistas e religiosos das lideranças políticas e dos legisladores nacionais.

Dessa forma, o direito à interrupção voluntária da gravidez parece estar fadado ao mutismo e à proibição, como se isso significasse a sua inexistência. Com o personagem Abortinho, Fabiane quebrou um código de silêncio visual que envolvia esse tema. A artista rompe com um tabu quando o personifica em suas tiras como o que ele é: um devir, algo que antecede o ser vivente. Quando estimula de forma aparentemente ingênua a dúvida, Abortinho colabora para o destronamento e a carnavalização das estruturas políticas conservadoras, sobretudo por estas fundamentarem seus argumentos em inferências morais que tentam se sobrepor a princípios constitucionais.

Ao dar destaque ao tema por meio do Abortinho, a questão parece ganhar outra concretude. Um debate que muitas vezes é desenvolvido de uma forma generalizante a abstrata, sem considerar as histórias de vida das pessoas envolvidas, suas subjetividades e outras questões que, muitas vezes, se tornam determinantes para suas escolhas.

As enunciações proferidas pelo personagem mostram-se capazes de interrogar e/ou desmistificar premissas aparentemente simples ou naturalizadas. Nestas, vislumbram-se as referências ideológicas as quais a artista se mostra afinada, ao mesmo tempo em que estabelece uma relação dialógica com as diferentes formações discursivas envolvidas nesse assunto, provocando, interpelando e contestando as suas proposições, numa incessante intertextualidade (FÁVERO, 1999).

Ao mesmo tempo que interpela a hipocrisia de nossas sociedades cristãs e burguesas, onde milhares de mulheres anualmente morrem ou correm risco 
de morte ao fazerem abortos de forma clandestina, ela mostra e denuncia de maneira ostensiva as péssimas condições em que o aborto vem sendo realizado nos subterrâneos das cidades.

$\mathrm{Na}$ análise que desenvolve sobre como a questão vem sendo politicamente tratada no Brasil, Flávia Biroli afirma:

o direito ao aborto é um eixo central da autonomia das mulheres. Sem o direito a controlar sua capacidade reprodutiva, a autonomia na definição de sua trajetória de vida fica fundamentalmente comprometida. (BIROLI, 2018, p. 135)

Creio que apesar das diferentes abordagens quadrinísticas no que tange ao aborto, um aspecto comum passível de ser identificado refere-se à compreensão de que "o privado e o íntimo são atravessados por relações de poder" (BIROLI, 2018, p. 133) e por isso é impossível tratar desse tema sem inserilo no debate sobre cidadania, os limites para a ação do Estado e os direitos das mulheres tanto na esfera pública, como no âmbito privado e doméstico. Não se refere aos direitos individuais, esse sujeito abstrato e sem relações concretas, mas ao direito das mulheres de se negar a aceitar o compulsório papel social “mulher-como-mãe".

À questão: "Qué significaciones tiene el aborto en el contexto político/social para que se exprese tan compacta resistencia?”, Gutierrez apresenta a seguinte resposta:

El aborto resignifica el empoderamento de las mujeres y pone en crisis la idea heteropatriarcal de la maternidad como destino para ellas. Es un acontecimiento, que sucede em el cuerpo y que pone en tensión múltiples y complejas decisiones. (GUTIÉRREZ, 2014, p. 10)

Ao colocar em discussão, imagética e discursivamente, regras impostas às mulheres em nome dos valores e convenções sociais e religiosas, Abortinho e o grotesco (BAKHTIN, 1993) nele representado, podem ser pensados como aliados importantes para demandas históricas dos movimentos feministas: o direito ao corpo, à vida, à saúde. O direito acima das opressões e do adestramento dos nossos corpos, sexualidade e afetos. 


\section{Referências}

ANGELO, Helô; GOMES, Joyce. Quatro Marias: uma reportagem em quadrinhos sobre as realidades do aborto no Brasil. [S.l.: s.n.], 2016. Disponível em https://quatromarias.com. Acesso em: 17 dez 2019.

BAKHTIN, Mikhail. A cultura popular na idade média e no renascimento: o contexto de Franc,ois Rabelais. São Paulo: Hucitec, 1993.

BIROLI, Flávia. Gênero e desigualdades: limites da democracia no Brasil. São Paulo: Boitempo, 2018.

BONACOSSA, Cynthia. Meu aborto em quadrinhos. Piauí, Rio de Janeiro, ed. 99, dez. 2014.

BONACOSSA, Cynthia. Pingue-pongue com Cynthia Bonacossa. Revista Risca! Memória e Política das Mulheres nos Quadrinhos, S.l.: Coletivo Lady's Comics, nov. 2015.

BRASIL. Proposta de Emenda Constitucional 181/2015, de 15 de dezembro de 2015, altera o inciso XVIII do art. 70 da Constituição Federal. Brasília, DF: Câmara dos Deputados, 2015. Disponível em:

https://www.camara.leg.br/proposicoesWeb/

prop_mostrarintegra?codteor=1425029\&filename=PEC+181/2015. Acesso em: 20 maio 2020.

BRASIL. Projeto de Lei no 5.069-A, de 2013. Acrescenta o art. 127-A ao DecretoLei no 2.848, de 7 de dezembro de 1940 - Código Penal. Brasília, DF: Câmara dos Deputados, 2013. Disponível em:

https://www.camara.leg.br/proposicoesWeb/prop_mostrarintegra;jsessionid=A4 A850F91D263A6E37C71C197B73477D.proposicoesWeb2?codteor=1404026\&filena me=Avulso+-PL+5069/2013. Acesso em: 20 Mai 2020.

CRESCENCIO, Cíntia. Quem ri por último, ri melhor: humor gráfico feminista (Cone Sul, 1975-1988). 2016. Tese (Doutorado em História) - Programa de Pósgraduac,ão em História, Universidade Federal de Santa Catarina, Florianópolis, 2016.

FÁVERO, Leonor Lopes. Paródia e Dialogismo. In: BARROS, Diana Luz Pessoa de; FIORIN, José Luiz (orgs.). Dialogismo, Polifonia e Intertextualidade em torno de Bakhtin. São Paulo: Editora da Universidade de São Paulo, 1999. 
FRANCO, Gabriela; MARINO, Dani. Aborto nas HQ de heróis. Minas Nerds, [S.L.], 27 set. 2016. Disponível em: https://minasnerds.com.br/2016/09/27/aborto-nashq-de-herois/. Acesso em: 17 dez 2019.

GUTIÉRREZ, Maria Alice. El Aborto y la autonomia de las mujeres: una lucha por la justicia. Clitoris: Sex(t)ualidades em Viñetas. Buenos Aires: Hotel de las Ideas, 2014.

HAYES, Leah. Not Funny Ha-Ha: a handbook for something hard. S.l. Fantagraphics, 2015. Disponível em:

http://www.fantagraphics.com/notfunnyhaha/. Acesso em: 17 dez. 2019.

LANGONA, Fabiane Bento A. Uma mulher cartunista? Explique-se sobre isso. Lugar de mulher é onde ela quiser. São Paulo, 17 mar. 2015. Disponível em: http://lugardemulher.com.br/uma-mulher-cartunista-explique-se-sobre-isso/. Acesso em: 04 jan. 2018.

LANGONA, Fabiane. Álbum de Fotos de Fabiane Langona no Facebook. [São Paulo], 2015. Disponivel em: https://www.facebook.com/pg/chiqsland/photos/ . Acesso em: 12 nov. 2019.

O QUE O PL 5069 DIZ... (E NÃO DIZ) SOBRE A PÍLULA DO DIA SEGUINTE: tire dúvidas. El País, São Paulo, nov. 2015. Disponível em: https://brasil.elpais.com/brasil/2015/11/12/politica/1447357721_656693.html Acesso em: 21 out 2019.

PIRES, Maria da Conceição Francisca. Mulheres desregradas: autorretratos e corpos grotescos nos cartuns de Fabiane. Topoi, Rio de Janeiro, v. 20, n. 41, p. 302-316, maio/ago. 2019a

PIRES, Maria da Conceição Francisca. Outras mulheres, outras condutas: feminismos e humor gráfico nos quadrinhos produzidos por mulheres. ArtCultura, Uberlândia, v. 21, n. 39, p. 71-87, jul./dez. $2019 b$.

RAGO, Margareth. A aventura de contar-se: feminismos, escrita de si e invenções da subjetividade. São Paulo: Editora Unicamp, 2013.

RODRIGUES, Marjorie. Na luta pelo aborto, será que ela foi longe demais? Revista AzMina, [S.l.], 05 jan. 2016. Disponível em: https://azmina.com.br/reportagens/na-luta-pelo-aborto-sera-que-ela-foilonge-demais/. Acesso em: 17 dez. 2019.

SILVA, Vitória R. da; MARTINS, Flávia B. Projetos de lei da Câmara contrários ao aborto batem recorde em 2019. Carta Capital, São Paulo, set. 2019. Disponível em: https://www.cartacapital.com.br/sociedade/projetos-de-lei-da-camaracontrarios-ao-aborto-batem-recorde-em-2019/. Acesso em: 09 maio 2020. 
TONIETTO, Chris. Projeto de Lei 2893/2019, de 14 de Maio de 2019, Revoga o art. 128 do Decreto-Lei no 2.848, de 7 de dezembro de 1940 (Código Penal), Brasilia, DF: Camara dos Deputados, 2019. Disponível em:

https://www.camara.leg.br/proposicoesWeb/prop_mostrarintegra;jsessionid=A21 3BE5AEA90A49D8699316B4BAA7BEE.proposicoesWebExterno2?codteor=174795 9\&filename=Tramitacao-PL+2893/2019. Acesso em: 20 maio 2020. 